\title{
1 Dextral strike-slip and normal faulting during middle Miocene back-arc extension and westward Anatolia extrusion in Central Greece
}

Agathe Faucher1 ; Frédéric Gueydan1 ; Marc Jolivet2 ; Manar Alsaif 1; Bernard

6

1 Géosciences Montpellier, Université de Montpellier, CNRS, Rue Eugène Bataillon, 34095

8 Montpellier, France.

92 Laboratoire Géosciences Rennes, Université Rennes 1, CNRS, avenue Général Leclerc, 35042, 10 Rennes, France.

Corresponding author: Frédéric Gueydan (frederic.gueydan@umontpellier.fr), Université de

Key Points

- Central Greece middle Miocene basins are controlled by the coeval activity of NEstriking dextral strike-slip and NW-striking normal faults

- $\quad$ The middle Miocene Pelagonian dextral strike-slip fault accommodated the differential extension rate between the Cyclades and Central Greece

- Plio-Quaternary deformation is controlled by E-striking normal faults and NW-striking fault zones, forming oblique rifts (Evvia, Corinth) 


\section{Abstract}

Present-day Aegean tectonics is marked by the interplay between Hellenic slab rollback and Anatolia extrusion, explaining the formation of extensional basins and dextral strike-slip faults. We aim to constrain, with structural analysis and low-temperature data, middle Miocene activity of dextral strikeslip and normal faults in Central Greece. We show that onshore middle Miocene basins are controlled by both NW-striking normal faults and NE-striking dextral strike-slip faults. E-striking normal faults developed during the Plio-Quaternary inside pre-existing NW-striking fault zones. Stress tensor calculations show that in middle Miocene, NW-striking normal faults and NE-striking dextral faults are compatible, confirming their coeval activity. In contrast, the Plio-Quaternary stress tensor suggests an almost N-S radial extension, which is not compatible with NE-striking dextral faults in Central Greece. Apatite Fission Track data additionally constrain middle Miocene local cooling near NW-striking normal faults. They also support a difference in the amount of exhumation between Central Greece and the Cyclades, likely accommodated by the Pelagonian dextral strike-slip fault. We propose that in the middle Miocene, the co-existence of dextral strike-slip and normal faults is associated with an almost $\mathrm{N}-\mathrm{S}$ extension related to trench retreat and an E-W compression related to westward extrusion of Anatolia. The progressive trench curvature during rollback implies block rotation, accommodated by the Pelagonian fault, and subsequent normal fault and extensional stress rotation. During the PlioQuaternary, a change in extensional direction from NE-SW to N-S implies the formation of E-striking normal faults inside NW-striking fault zone, defining oblique rift systems. 


\section{Introduction}

Present-day Aegean tectonics activity is marked by the interplay between westward Anatolian extrusion and southward Hellenic slab rollback (Fig. 1, inset for GPS velocity field - Reilinger et al., 2006; Hollenstein et al., 2008; Pérouse et al., 2012). The Aegean domain is the upper plate of the Hellenic subduction that is active since Jurassic times (Clift and Dixon, 1998; Papanikolaou, 2013). The lower subducting plate was composed of three main micro-continents separated by two main oceans or deep basins. Subduction led to the progressive accretions of these continental terranes and the formation of the nappe stack that characterizes the Aegean domain; from bottom to top: Adria with some fragments of Pindos ocean, Pelagonia and minor fragments of Vardar ocean in Rhodope (Fig. 1 - Aubouin, 1965; Papanikolaou, 1997, 2013). Southward Hellenic subduction slab rollback caused subsequent upper plate extension that is proposed to be mainly accommodated by several low-angle detachment systems with the formation of Metamorphic Core Complexes (MCC - Lister et al., 1984; Gautier et al., 1993; Vandenberg and Lister, 1996; Faccenna et al., 2003; Jolivet, 2003; Jolivet et al., 2010a; Brun and Faccenna, 2008; Brun et al., 2016; Brun and Sokoutis, 2018; Grasemann et al., 2012, 2018). From the middle Miocene to present, trench retreat accelerated and led to both ongoing activity of low-angle normal faults (Avigad and Garfunkel, 1989; Forster and Lister, 1999; Tschegg and Grasemann, 2009; Krohe et al., 2010; Iglseder et al., 2011) and the development of NW-striking high-angle normal faults (e.g parallel to the retreating trench) and extensional basins at the scale of the whole Aegean (Fig. 1, orange basins- Mascle and Martin, 1990; Brun et al., 2016). In this context, Central Greece, the Peloponnese and the North West Cyclades rotated clockwise by 25 to $50^{\circ}$ (Horner and Freeman, 1983; Kissel et al., 1986, 2003; Duermeijer, 2000; van Hinsbergen et al., 2005, 2006; Bradley et al., 2013) around the Scutari Pec pole (Speranza et al., 1992), and the South East Cyclades rotated counterclockwise ( 30 - van Hinsbergen et al., 2007, 2010; van Hinsbergen and Schmid, 2012 - Fig. 1). During the Plio-Quaternary, the formation of the large dextral North Anatolian strike-slip Fault (NAF) accommodating westward Anatolian extrusion, is associated with plate kinematics re-organisation and a modification of Aegean extension (Fig. 1 - Armijo et al., 1999, 2004; Hubert-Ferrari et al., 2002, 2003; Flerit et al., 2004). This plate re-organisation led to the formation of the Aegean/Anatolia microplate (highlighted by the GPS velocity field in Fig 1). The connection from the NAF to the subduction zone (near Kephalonia) marked diffuse Anatolia/Aegean plate boundary, also called the Central Hellenic Shear zone (CHSZ - Fig. 1- McClusky et al., 2000; Goldsworthy et al., 2002;

100 Papanikolaou \& Royden, 2007; Royden \& Papanikolaou, 2011). It is characterized by major strike-slip zones to the North and South (NAF, Kephalonia) and major E-striking normal faults in the centre 102 (Corinth and Evvia rift - Fig. 1). The Corinth and Evvia rifts have been proposed to have opened at the 103 tip of the propagating NAF during the Plio-Quaternary (Armijo et al., 1996; Flerit et al., 2004). Note 104 that several NE-striking dextral strike-slip systems are also identified from seismological and geodetic 
105 data inside the Aegean domain, with assumed Plio-Quaternary activity (bolded lines in Fig. 1 106 Sakellariou \& Tsampouraki-Kraounaki, 2019).

107 Several observations, however, question this classical view of Aegean tectonics, suggesting active 108 strike-slip faulting also during middle Miocene times. First, the extrusion of Anatolia could have started 109 earlier during the middle/early Miocene as recently suggested by syn-tectonics calcite dating of the 110 NAF fault plane (Nuriel et al., 2019). At this time, extrusion was accommodated in a broader 111 deformation zone called the North Anatolian Shear Zone (Şengör et al., 2005). Second, the presence of 112 syn-kinematic dextral structures in middle Miocene plutons in the Cyclades suggest middle Miocene 113 activity of at least some NE-striking dextral strike-slip faults (Kokkalas, 2001; Koukouvelas and 114 Kokkalas, 2003; Kokkalas and Aydin, 2013). Note, however, that these middle Miocene plutons are 115 proposed to be potentially associated with detachment faulting or extensional shear zones (van 116 Hinsbergen and Schmid, 2012; Rabillard et al., 2015; Menant et al., 2016; Malandri et al., 2017; 117 Bessiere et al., 2018). The Myrthes-Ikaria Fault (also called the mid-Cycladic lineament - Fig. 1, 118 Walcott \& White, 1998) is moreover proposed to be a major dextral strike-slip fault during the middle 119 Miocene. This fault may have accommodated Miocene block rotation in the Cyclades, as suggested by 120 the differences in the lineation trends between the North-West Cyclades and the Central Cyclades 121 (Philippon et al., 2012; Brun et al., 2016).

122 In order to provide new constraints on potential middle Miocene activity of NE-striking strike-slip 123 faults, Central Greece (including the Attica and Evvia regions) is a key place for the three following 124 main reasons. First, the majority of NE-striking faults of the Aegean domain are described offshore 125 (Fig. 1, Sakellariou and Tsampouraki-Kraounaki, 2019). The Pelagonian fault in Evvia (Central Greece, 126 Fig. 1), is one of the rare NE-striking structures cropping out onshore over a long horizontal distance. 127 This fault is a first order structure since it separates Pelagonia-derived rocks from Adria/Pindos 128 (structurally below Pelagonia)-derived rocks (Fig. 1). However, its kinematics is still discussed: normal 129 slip (Papanikolaou and Royden, 2007; Diamantopoulos et al., 2009) or dextral strike slip (Kokkalas, 130 2001; Xypolias et al., 2003). The age of its activity is also debated, as it is not clear if it has been active 131 only during the Plio-Quaternary or also during the middle Miocene (Kokkalas, 2001; Xypolias et al., 132 2003; Bradley, 2012; Sakellariou et al., 2013). Second, Miocene extensional tectonics activity in the 133 Cyclades has been widely studied, with the existence of several major detachment systems (Gautier et 134 al., 1993; Jolivet et al., 2010b; Iglseder et al., 2011; Scheffer et al., 2016), while Miocene tectonics of 135 Central Greece is less constrained. The presence of strike-slip deformation together with NW- striking 136 high-angle normal faulting in Central Greece is proposed to be active since the middle Miocene inside 137 the Central Hellenic shear Zone (Fig. 1, Papanikolaou \& Royden, 2007; Royden \& Papanikolaou, 138 2011). Miocene deformation is also well-marked in the area through numerous middle Miocene basins 139 whose tectonics context of deposition remains to be characterized (Fig. 1, Bornovas and Rondogianni140 Tsiambaou, 1983). Third, low-temperature thermochronology ages provide an important constraint on 141 the deformation history of rocks during their last stage of exhumation in the upper crust. The Cyclades 
142 have been extensively studied from this point of view with a clear middle to late Miocene cluster in age 143 (Hejl et al., 2002, 2008; Ring et al., 2003, 2007; Brichau et al., 2006, 2008; Seward et al., 2009; Berger 144 et al., 2013; Soukis and Stockli, 2013; Seman, 2016; Grasemann et al., 2018; Schneider et al., 2018) 145 highlighting important exhumation/extensional events at that time, related to detachment faulting 146 (Brichau et al., 2008; Jolivet et al., 2010a; Krohe et al., 2010; Iglseder et al., 2011; Grasemann et al., 147 2018) and/or the coeval activity of high-angle normal faulting and strike-slip faulting during block 148 rotation (Philippon et al., 2012; Brun et al., 2016). In contrast to the Cyclades, the absence of low 149 temperature data in Central Greece (Fig. 1) obscures the timing and tectonics context of its exhumation 150 and a comparison with the Cyclades.

151 The objective of this study is to provide new structural and geochronological constraints in Central 152 Greece in order to characterize the role of both normal faults and NE-striking dextral faults (Pelagonian 153 Fault, Fig. 1) during the formation of two middle Miocene basins inside the island of Evvia and Attica

154 (Fig. 1). Furthermore, new low-temperature apatite fission-track (AFT) data acquired from the 155 Pelagonian rocks will allow a quantification of their exhumation history and hence a possible 156 comparison to the Cyclades.

\section{2. Geological setting}

160 Central Greece is formed by the stacking of Pelagonia-derived rocks on top of Adria-derived rocks, separated by Pindos and Parnassos flysch and/or ophiolites (remnants of the Pindos ocean/deep basin -

162 Figs 1 and 2 - Papanikolaou, 2013). Pelagonian rocks mainly crop out in the north-west of Attica and 163 in the island of Evvia while Adria (some fragments of Pindos ophiolites) rocks are exposed in Western 164 Central Greece, in the South of Evvia and in all the Cyclades (Figures 1 and 2). The Pelagonian Fault 165 (PF - also called South Evvia North Attica fault, Bradley, 2012 - orange line in Fig. 2) limits the 166 Pelagonian and Adria/Pindos terranes in both Evvia and Attica (Xypolias et al., 2003).

167 Pelagonia is composed of two main units from bottom to top: 1/ Crystalline basement composed of a 168 para- and orthogneiss with Cambrian ages (Yarwood et al; 1976, orange in Fig. 2); 2/ (Meta)169 Sedimentary cover (pink, Fig. 2) with Permian metasediments and metavolcanics, Triassic to Jurassic 170 marbles, and limestone (Doutsos et al., 1993; Ross \& Zimmerman, 1996). These units are thrusted on 171 top of the Mesozoic to Lower Tertiary Beotian and Parnassos Flysch (Faupl et al., 2007; Nirta et al., 172 2015). They have undergone greenschist facies metamorphism during the Early Cretaceous and locally 173 underlie ophiolites (dark green, Fig. 2).

174 The Pindos unit (between Pelagonia and Adria rocks) mainly crops out in western Central Greece and 175 is composed of Paleocene to Eocene flysch (Faupl et al., 2007).

176 Adria rocks are typical of continental rifted margin with contrasting deformation histories from west to 177 east (and from bottom to top): 1/ deformed sediment plateform with a fold and thrust belt defining the 178 External Hellenides locally named Ionian, Plattenkalk, Phylitte and Gavrovo tripolitza units (Aubouin, 
179 1959; Bonneau, 1984; Doutsos et al., 2006); and 2/ the Cyclades Blueschist Units which are composed 180 of Adria/Pindos derived rocks with HP/LT metamorphism (CBU, Bonneau, 1984). The CBU can be 181 subdivided in three main units (Bonneau, 1984; Trotet et al., 2001; Philippon et al., 2012): i/ basement 182 (gneiss and pelitic shales), ii/ metasedimentary cover (Triassic marbles and Mesozoic sediments), and 183 iii/meta-ophiolitic rocks (serpentinite, meta-basalt, meta-chert, metagabbro) on top with well-preserved 184 HP-LT assemblages (e.g Syros, Philippon et al., 2013). The basement and sedimentary cover correspond to the distal part of the Adria margin and the meta-ophiolite to the Pindos Ocean (Philippon et al., 2012). The CBU is also exposed south of Evvia and Attica (called Evvia Blueschist Unit - EBU - Katsikatsos et al., 1986; Katzir et al., 2000; Xypolias et al., 2003) and are thrust onto the autochthonous Almyropotamos unit, which is the lateral equivalent of the external Hellenides (Gavrovo, Shaked et al., 2000; Ring et al., 2007; Jolivet et al., 2013, Fig 2). The Almyropotamos unit consists of $1.5 \mathrm{~km}$-thick of Eocene-Oligocene metaflysch above $2 \mathrm{~km}$-thick of Triassic-middle Eocene marbles interspersed with shales.

192 Numerous Neogene basins cover this Aegean domain, with the majority being Pliocene-Quaternary in 193 age. They are also coeval with plate re-organisation and the formation of the North Anatolian Fault and 194 the Corinth and Evvia rift systems (see §Introduction and Figure 2 in Brun et al., 2016; see also Mascle and Martin, 1990). We will focus our study on middle Miocene basins (Figs. 1 and 2), cropping out in Central Greece. They are mainly filled with lacustrine and alluvial sediments (limestones and conglomerates) and dated at around $14 \mathrm{Ma}$ through $\mathrm{K}-\mathrm{Ar}$ ages from syn-sedimentary volcanism

198 (Oxylithos unit in Kymi Basin in Evvia, Katsikatsos et al., 1981; Pe-Piper and Piper, 1994; Bradley, 199 2012). In the CBU, in the Peloponnese and in Crete, Miocene extensional tectonics is supposed to be mainly controlled by low-angle normal faults (detachments). In particular, three major detachment systems have been described in South Attica/Cyclades: the North Cycladic Detachment, the West Cycladic Detachment (Lavrion detachment in Attica) and the Naxos-Paros/Central Cycladic Detachment (Gautier et al., 1993; Jolivet et al., 2010a; Iglseder et al., 2011; Scheffer et al., 2016; Coleman et al., 2019). The Cretan detachment is mapped in Crete (Ring et al., 2001), while the CorinthPatras detachment has been described (Sorel, 2000) and debated (Bell et al., 2009) north of the Peloponnese. Contrastingly, the Neogene basins (middle Miocene and Plio-Quaternary) in Central Greece are proposed to be controlled by high-angle faults (Papanikolaou \& Royden, 2007; Royden \& Papanikolaou, 2011). Plio-Quaternary basins are controlled by E-striking high-angle faults, defining the major rift shoulders in Evvia and Corinth (Moretti et al., 2003; Bell et al., 2009). NW-striking high-

210 angle normal faults (Figs. 1 and 2), observed throughout Central Greece and the Peloponnese, are 211 proposed to control the middle Miocene basins deposition by reactivation in extension of former thrust 212 faults (e.g. Pindos/Adria limits or Pelagonia/Pindos limit, Fig. 1 and 2; Papanikolaou and Royden, 213 2007). These high-angle faults are seismically active today with dip-slip normal (E-striking faults) and 214 oblique sinistral and normal (NW-striking faults) kinematics (Roberts and Jackson, 1991; Kiratzi and 215 Louvari, 2003; Papanikolaou and Royden, 2007; Ganas et al., 2016). middle Miocene basins in Evvia 
216 and Attica are also observed close to the NE-striking Pelagonian Fault (Figs. 1 and 2), which is initially

217 a thrust formed during subduction nappe stacking, separating Adria and Pelagonia (Papanikolaou,

218 2013). The age of the activity of the Pelagonian Fault is controversial, with a potential middle Miocene

219 age (Kokkalas, 2001; Xypolias et al., 2003). The Pelagonian Fault was characterized as a normal fault

220 because of differential exhumation in the footwall (CBU) and hangingwall (Pelagonia) (Shaked et al.,

221 2000; Papanikolaou and Royden, 2007; Diamantopoulos et al., 2009) or even as an extensional transfer

222 fault (Bradley, 2012).

223 Our objective is to constrain the tectonics history of Central Greece (Evvia and Attica) from the middle

224 Miocene to the present. To achieve our purpose, we will:

225 1/ Constrain the potential strike-slip activity of the Pelagonian Fault during middle Miocene times and 226 its relation with middle Miocene basin deposition. To this end, we study the tectonics context of two 227 middle Miocene basins: Limni (North Evvia) and Kymi (South Evvia) basins (Fig. 2). The Kymi basin 228 was chosen for its proximity with the Pelagonian Fault and it will be compared with the Limni basin, 229 which has no NE-striking structures. In particular, we aim to constrain the link between the activity of $230 \mathrm{NW}$-striking high-angle normal faults and NE-striking strike-slip faults in middle Miocene times.

231 2/ Characterize the link between NW-striking and E-striking normal faults to constrain the role of 232 middle Miocene inherited structures in controlling Plio-Quaternary faulting.

233 3/ Acquire new Apatite Fission Track data (AFT) to constrain the exhumation history of Central Greece 234 and its relationship to faults activity. This work will also provide the first AFT dataset in this region 235 (Fig. 1).

236

\section{Structural data}

\subsection{The Limni basin and NW-striking normal faults}

240 The northern middle Miocene Limni basin is located in the central part of northern Evvia (Fig. 3) and contains lacustrine limestones, conglomerates and shales deposited on different units of Pelagonia: the basement (gneiss and Permo-Carboniferous sediment) in the southern rim, Triassic-Jurassic marble/schists and ophiolites to the north and east (see geological setting and Fig. 3).

244 We conducted a structural study with around 125 bedding measurements in the basin (stereonet of basin's sediment beddings in Fig. 3B) and 83 faults measurements in the Pelagonian bedrock and Miocene basin fill (stereonets of total faults shown in Figure 3B).

247 The structural map in Figure 3 shows the major faults inferred from our field study. Two main strike 248 directions are observed: NW-SE and E-W (map and stereonets of Fig. 3). Note that minor NE-striking 249 faults with horizontal slickenlines suggesting strike-slip motion and N-S faults are observed (location 250 III, Fig. 3A). At map scale, the basin is controlled in its southern rim by a major NW-striking highangle normal fault (fault 1, Fig. 3A), locally defining a NW-striking faulted zone in highly deformed 
Pelagonian rocks (stereonet in location I, Fig. 3B and right picture in Fig. 3D). Local observations of NW-striking normal faults with slickenlines show two families of slickenlines, one with dip slip and one with slightly oblique slip (location II, Fig. 3A, stereonet in location II, Fig. 3B and left picture, Fig. 3D). Local observation on a fault plane with the two slickenlines suggest first a dip slip activity on NW-striking normal fault and a more recent oblique slip on the same fault. The present-day seismic activity shows consistently oblique sinistral on NW-striking faults (Roberts and Jackson, 1991; Papanikolaou and Royden, 2007; Ganas et al., 2016). On these bases, we will define therefore two fault families: NW-striking with dip slip (supposed to be active in middle Miocene, see below) and NWstriking with oblique slip (supposed to be active in Plio-Quaternary as suggested by the present-day seismic activity - Ganas et al., 2016)

A NE-SW cross-section (orthogonal to the major normal fault 1, Fig. 3C) shows the relationship between NW-striking faults and the basin bedding. It highlights a major offset of the Pelagonian basement in the footwall by the NW-striking fault 1 and the Pelagonian marble and schist, covered by middle Miocene sediments in the hangingwall. This observation implies a minimum vertical offset of the thickness of the marble/schists and of the ophiolite unit of the Pelagonian which is at least 1 to $2 \mathrm{~km}$ thick (Xypolias et al., 2003). In the basin, minor NW-striking normal faults are observed with limited offset in the Pelagonian bedrock (faults 2, 3 and 4), as shown in cross-section Fig. 3C. Although the Limni basin is bordered and internally affected by NW-striking normal faults, the dip of the bedding is relatively flat (stereonet of basin's sediment beddings, Fig. 3B), with a mean dip value of around $30^{\circ}$ and a mean strike of NW-SE. Furthermore, our bedding measurements suggest that the basin thickness slightly increases in the hangingwall of major faults (like fault 1, cross-section in Fig. 3C). This observation suggests that NW-striking faults are synchronous with basin deposition.

These NW-striking normal faults strongly affect the Evvia and Attica areas (Fig. 2 and 3) by controlling the mean strike of the Evvia Gulf. Locally NW-striking normal faults are cross-cut by E-striking normal faults (location I, Fig. 3A, stereonet in location I, Fig. 3B and right picture, Fig. 3D). At map scale, this observation is also validated. In the Northern part of Evvia, near Loutra Edipsou, the coastline evolves from a NW-SE strike in the South to an E-W strike to the North showing the interplay (observed at small scale at locations IV and V, Fig. 3A and stereonets in location IV and V, Fig. 3B) between NWstriking normal faults and E-striking normal faults.

\subsection{Loutra Ypatis: E-striking and NW-striking normal faults}

The western termination of the Evvia Gulf also shows remarkable interactions between NW- and Estriking fault structures.

The active Kamena Vourla fault (location I, Fig. 4A, stereonet in location I in Fig. 4B and pictures a-b in Fig. 4C - Cundy et al., 2010; Walker et al., 2010), defining the southern rim of the Evvia Gulf and visible from the Athena-Thessaloniki highway, shows a large fault plane with slickenlines (pictures ab in Fig. 4C). Our data suggest two dominant strikes: E-W and NW-SE. NW-striking faults evolve 
locally to an E-W strike with the same slickenlines (location I in Fig. 4A and stereonet in location I, Fig. 4B). Similar features have been observed south of the Limni basin (Loutra Edispou - locations IV and V, Fig. 3A, and see details in the above section 3.1). At map scale, the Kamena Vourla fault system is part of an E-W en-échelon-system inside a NW-striking zone, explaining these two strikes.

293 This en-échelon system is found at larger scale, with five main E-striking fault segments from East to

294 West: Arkitsa (already characterized with high resolution data by Jackson and McKenzie, 1999; 295 Kokkalas et al., 2007), Kamena Vourla (location I, Fig. 4A), Thermopyles (location III, Fig 4A and stereonet in location III, Fig. 4B), Loutra Ypatis (location V, Fig. 4A, stereonet in location V, Fig. 4B and picture c, Fig 4C) and Lefkada. These E-striking fault segments are connected by NW-striking normal faults mapped in location II and IV (stereonets in locations II and IV in Fig. 4B) and NWstriking fault in west of Arkitsa fault and Kamena Vourla fault (location I, Fig. 4A). This en-échelon system defines the southern rim of the Evvia Gulf which is therefore, a NW-SE oblique rift with active E-striking normal faults.

\subsection{Normal faults and stress tensors in Limni and Loutra Ypati areas}

\section{3.a. Inversion method}

We invert our measured fault and slip data for paleostress. The inversion seeks a stress tensor that yields a shear stress direction on each fault plane as close as possible to the measured slip direction (Wallace, 1951; Bott, 1959; Angelier, 1984). We use the Fsa software (Burg et al., 2005; Célérier, 2020) that implements the random search method proposed by Etchecopar et al. (1981). This method allows inverting either the whole dataset in the case of monophase data, or only a fraction of the dataset in the case of polyphase data. It yields the principal stress directions $\mathrm{s}_{1}, \mathrm{~s}_{2}, \mathrm{~s}_{3}$, and stress tensor aspect ratio $\mathrm{r} 0$

$312=(\sigma 1-\sigma 2) /(\sigma 1-\sigma 3)$, where $\sigma 1 \geq \sigma 2 \geq \sigma 3$ are the principal stress magnitudes corresponding to the 313 directions $s_{1}, s_{2}, s_{3}$. We use the quality criterion proposed by Heuberger et al. (2010) to distinguish 314 robust solutions from possible statistical artifacts. It is based on a comparison between the total number 315 of data in the data set, Ntotal, the number of data with a rake misfit lower than $15^{\circ}, N \exp 15$, and the 316 number of data NOexp15 that could be obtained below the same misfit threshold by inverting a random 317 dataset of the same size Ntotal. The result of this comparison is summarized by an integer quality index, 318 InvQual, that varies from -1, for solutions that could be artifacts, to 2 for robust estimates. Because each 319 data set is partly heterogeneous, each inversion is carried out in two steps to cancel the influence of 320 outliers on the solution. In a first step, all data are considered, and the proportion of data with acceptable angular misfit (below 15 or $30^{\circ}$, depending on cases) is determined. In a second step, the inversion is required to account only for that proportion of data. To facilitate the discussion of the results, we will call a fault slip datum compatible or incompatible with a stress tensor when the angular misfit between its slip vector and the predicted shear stress direction is less than $15^{\circ}$ or more than $30^{\circ}$ respectively. We 
325 will also distinguish the terminology for tectonics regimes, compressional, wrench, and extensional, 326 following Célérier (1995), from that of fault types, reverse, strike-slip, and normal.

327

328

329

330

331

332

333

334

335

336

337

338

339

340

341

342

343

344

345

346

347

348

349

350

351

352

353

354

355

356

357

358

359

360

361

\section{3.b. Dataset}

Our structural data show that Limni and Loutra Ypatis areas are controlled by three families of faults: family $1 /$ E-striking normal faults, family $2 / \mathrm{NW}$-striking normal fault with oblique-slip (strike-slip faults), and family 3/ NW-striking normal faults (e.g. with dip slip). Families 2 and 3 having similar fault plane orientations with markedly different slip orientations suggests that they belong to distinct tectonics phases, which is further supported by occasional slickensline record of these different slips on the same fault. Families (1) and (2) are seismically active today (Roberts and Jackson, 1991; Papanikolaou and Royden, 2007; Ganas et al., 2016), Our structural data show that NW-striking faults (with dip slip, Family 3 ) are synchronous with middle Miocene basin deposition. Family 3 was therefore active in middle Miocene, at a different period of time compare with families 1 and 2. We combined families 1 and 2 and kept the family 3 separated for the inversions, to obtain, respectively, a PlioQuaternary stress tensor and a middle Miocene stress tensor.

\section{3.c. Results}

The resulting stress tensors are labeled with a subscript that indicates the family combination they are calculated from: $T_{3}$ is computed from family 3 , while $T_{12}$ is computed from the combination of families 1 and 2. They are shown in stereographic projection with the data they are computed from in Fig. 5. Their parameters are listed in supplementary material Table ST1 while the inversion parameters and quality are documented in Table ST2. Detailed misfit distributions and Mohr's circles are shown in Appendix (Fig. S1 and S2).

The combination of the two first families yields 40 faults and slip data and reduced stress tensor $\mathrm{T}_{12}$ with nearly vertical maximum principal stress $s_{1}$, thus in the extensional regime (Fig. 5A and supplementary materials Tables ST1 and ST2). The minimum principal stress, $\mathrm{s}_{3}$, is horizontal and oriented North-South. However, the aspect ratio, $\mathrm{r} 0=0.92$, places the regime close to radial extension and thus suggests that the orientations of the horizontal principal stress are not highly significant. This solution yields an average angular error of $8.1^{\circ}$ for $75 \%$ of the data, and accounts for 25 faults with rake misfit below $15^{\circ}($ Nexp15 $=25)$, which ensures a high statistical significance with InvQual $=2$ (supplementary material Table ST2).

The third family contains 15 data and yields stress tensor $\mathrm{T}_{3}$ also in the extensional tectonics regime with a horizontal minimum principal stress, $\mathrm{s}_{3}$, oriented NE-SW (Fig. 5B). The aspect ratio, $\mathrm{r} 0=0.8$, places the regime into a typical extension, further away from radial extension than $\mathrm{T}_{12}$. The average angular error is $7.7^{\circ}$ for $100 \%$ of the data, and 12 faults have rake misfit below $15^{\circ}(N \exp 15=12)$, but the small number of data results in a lower quality solution with InvQual = 1 (supplementary material Table ST2). 
This inversion therefore suggests:

1/ Almost radial extension during Plio-Quaternary (tensor $\mathrm{T}_{12}$ with $\mathrm{s}_{3}$ orientated N-S) associated with dip-slip motion on new-formed E-striking normal faults and oblique sinistral and normal motion on preexisting NW-striking normal faults

2/ NE-SW extension along NW-striking normal faults during middle Miocene times

\subsection{The Kymi basin: NW-striking normal faults and NE-striking dextral faults.}

369 Our structural analysis on the middle Miocene Kymi basin (location on Figure 2 and local map in Fig. 370 6A) allows the identification of the key faults controlling the sediment deposition. From bottom upwards, the basin contains lacustrine and conglomerate deposits (Bradley, 2012). Oxylithos volcanics intruded the basin during sediment deposition at 14 Ma (Fig. 6A, Pe-Piper \& Piper, 1994) allowing relative dating of the basin to be middle Miocene. The basement of the basin is composed of Pelagonian rocks (Paleozoic, Triassic-Jurassic marble and schists and Cretaceous sediments), forming large scale open folds: NE-SW Amarynthos antiform and synform below the basin (Fig. 6A, Xypolias et al., 2003; Bradley, 2012). Similar folds are observed in the Adria unit (EBU, Almyropotamos antiform, Kokkalas, 2001; Xypolias et al., 2003). At map scale, the Pelagonian Fault separates the Pelagonian (to the North) from the EBU (to the South) and marks the southern limit of the Kymi basin (orange line in Fig. 6). We extended our analysis to the Nea-Palatia middle Miocene basin in Central Greece (Fig. 6A) in order to constrain the southern continuity of the Pelagonian Fault. Our study yielded 185 fault measurements (Fig. 6B stereonet of total faults), mainly outside of the basin, and 354 bedding measurements (Fig. 6B stereonet with 44 basin's sediment beddings).

383 Two main fault directions with map-scale fault trace exposure were observed: NW-striking normal

384 faults and NE-striking sub-vertical strike-slip faults parallel to the map scale strike of the Pelagonian 385 Fault (stereonets in Fig. 6B). Minor E- and N-striking faults are observed, with no clear map-scale fault 386 trace exposure (stereonets, Fig. 6B).

387 In the Kymi basin, NW-striking normal faults are found in the south-western part of the basin marking the contact between lacustrine sediments and Pelagonian rocks (location I in Fig. 6A and stereonet in location I, Fig. 6B). Similarly, the northern rim of the Kymi basin is mainly controlled by NW-striking normal faults (as already discussed in Bradley, 2012), a feature that is similar to our findings in the Limni basin. Associated with these normal faults, we found NE-striking vertical faults, with subhorizontal slickenlines and a dextral shear sense, defining a NE-striking corridor that limits the Kymi basin (location II, Fig. 6A and stereonet in location II, Fig. 6B). The southern limit of the Kymi basin is mainly controlled by these NE-striking faults (e.g. Pelagonian Fault, PF).

395 The novelty of our data is to provide numerous fault data with vertical plane and horizontal slickenlines 396 along the Pelagonian Fault (locations III-IV, Fig. 6A, stereonets in locations III-IV, Fig. 6B and picture in Fig. 6C) that will be used for the stress inversion (see below). At location III, the Pelagonian marbles are strongly deformed, forming either large breccias or defining a new sub-vertical NE-striking 
schistosity at high-angle to the regional schistosity of Pelagonian schists (picture in Fig. 6D). Even in this strongly faulted zone, NW- striking normal faults are always observed, with no cross-cutting relationships, suggesting a possible coeval activity of strike-slip and normal faults (Fig. 6B, stereonets in locations III-IV and V). At map scale, the Pelagonian Fault defines the southern rim of the basin (cross-section Fig. 6E) indicating activity of the fault after or during the deposition of the Kymi basin. In addition, sub-horizontal bedding of the basin, even close to the PF, suggests that the basin is not deformed by the Pelagonian Fault (stereonet of basin's sediment beddings in Fig. 6B and cross-section, in Fig. 6E), indicating basin deposition during the PF activity (as already suggested by Kokkalas, 2001; Xypolias et al., 2003).

Similar conclusions can be drawn in the Nea-Palatia basin in Attica. The southern/eastern rim of the middle Miocene basin is marked at map scale by NE-striking dextral strike-slip faults (locations VI in Fig. 6A and stereonet in location VI in Fig. 6B). Note again the existence of NW-striking normal faults inside or close to NE-striking strike-slip faults, suggesting a potential coeval activity of normal faults and strike-slip fault (location VII in Fig. 6A and stereonet on location VII in Fig. 6B). This dextral fault zone is not directly continuous from the Pelagonian Fault in Evvia, suggesting two branches: one northern branch in Evvia, one southern branch in Central Greece. The northern branch (the Pelagonian Fault in Evvia) most probably ends inside the Evvia Gulf and leads to limited deformation in Central Greece (northern location VI in Fig. 6A). These two branches define a strike-slip corridor at regional scale (Fig 6A).

\subsection{Stress tensor for the NE-striking strike-slip faults.}

The 25 NE-striking strike-slip faults from the Kimi area define our 4th family of faults. Inverting it yields a new stress tensor $\mathrm{T}_{4}$, a good quality solution (Table ST2), with a nearly vertical intermediate principal stress, $\mathrm{s}_{2}$, thus in the wrench tectonics regime, and with a horizontal minimum principal stress, $\mathrm{s}_{3}$, oriented North-South (Fig. 7 and supplementary materials S3 and Table ST1). An average angular error of $4.5^{\circ}$ for $76 \%$ of the data and 19 faults with rake misfit below $15^{\circ}(N \exp 15=19)$ result in a good quality: InvQual = 2 (supplementary material Table ST2). This stress tensor is different from the stress tensors inferred from E-striking normal faults with NW-SE oblique sinistral faults $\left(\mathrm{T}_{12}\right)$ and NWstriking normal faults with dip-slip $\left(\mathrm{T}_{3}\right)$, due to the differences on the vertical principal stress axis: $\mathrm{T}_{12}$ and $\mathrm{T}_{3}$ are in extensional regime ( $\mathrm{s}_{1}$ vertical) while $\mathrm{T}_{4}$ is in wrench regime ( $\mathrm{s}_{2}$ vertical). In the discussion section, we will discuss the compatibilities between $\mathrm{T}_{3}$ and $\mathrm{T}_{4}$, since our field data suggest coeval activities of NE-SW strike-slip and NW-SE normal faults with dip slip.

$$
\text { For } \mathrm{T}_{4} \text { stress tensor, the maximum principal stress direction } \mathrm{s}_{1} \text { is horizontal and orientated E-W (Fig. }
$$

7). Large scale folds in the Pelagonian rocks and the EBU, orientated N-S, are consistent thus consistent with this inferred shortening direction and hence with dextral strike-slip activity of the Pelagonian Fault (Fig. 6A, Fig. 7C). Moreover, the parallelisation of the fold axes evolving from N-S to NE-SW towards 
the Pelagonian Fault supports coeval PF activity and folding (Xypolias et al., 2003). Kymi basin deposits in a NE-SW oriented syncline, suggesting deposition during strike-slip activity (Fig. 6E).

\section{Low-temperature thermochronology data}

\subsection{Method}

441 We conducted Apatite Fission Track (AFT) analysis to constrain the exhumation history of the 442 Pelagonian rocks in Central Greece, since no data are presently available in this region (Fig. 1). Samples 443 were selected along a transect perpendicular to the Pelagonian Fault to characterize its impact on rock 444 exhumation (samples location on Fig. 2 and Figs. 3,4,6). This new dataset, together with previous zircon 445 fission track (ZFT), AFT and (U-Th)/He ages from Central Greece, will permit a comparison to 446 published ages in the Cyclades that cluster around 10-12Ma, potentially revealing the role of the 447 Pelagonian Fault on regional exhumation (Fig. 1, and see our Introduction and Geological setting for 448 further details).

449 The AFT thermochronology data provide thermal information within a $60^{\circ} \mathrm{C}$ to $120^{\circ} \mathrm{C}$ temperature 450 range, allowing us to describe the exhumation or burial of rocks within the upper 2 to $5 \mathrm{~km}$ of the crust 451 (Gleadow \& Duddy, 1981). AFT data will therefore be used to identify the last stage of exhumation in 452 the upper crust and the potential role of the faults. Some samples were chosen close to the identified 453 NW-striking faults, to provide further constraints on their age.

454 Six key-samples were selected (location Fig. 2): CG03 (Pelagonian schists close to Pelagonian Fault), 455 CG08 (metamorphic Pelagonian schists), CG11 and CG13 (Pelagonian metamorphic basement), CG14 and CG16 (Pindos Flysch). CG11, CG13, CG16 and CG14 are located on the footwall of NW-striking normal faults.

458 The apatite samples were mounted on glass slides using epoxy glue and polished. Samples were etched 459 in $6.5 \% \mathrm{HNO} 3(1.6 \mathrm{M})$ for 45 seconds at $20^{\circ} \mathrm{C}$ to reveal the spontaneous fission tracks (Seward et al., 460 2000), before being irradiated with a neutron fluence rate of $1.0 \times 1016$ neutrons $/ \mathrm{cm} 2$ (Oregon State 461 University, Oregon, U.S.A.). The micas used as external detector were etched in $40 \% \mathrm{HF}$ for 40 minutes at $20^{\circ} \mathrm{C}$ in order to reveal the induced fission tracks. The ages were calculated following the method recommended by the Fission Track Working Group of the I.U.G.S. Subcommission on Geochronology

464 (Hurford, 1990) using the zeta calibration method (Hurford \& Green, 1982). CN5 glass was used as a dosimeter. Ages were calculated using an overall weighted mean zeta value of $313.2 \pm 11.96 \mathrm{a} \mathrm{cm} 2$, obtained on both Durango (McDowell et al., 2005) and Mount Dromedary apatite standards (Green, 1985; Tagami, 1987). Samples were analyzed at the University of Rennes 1 - Observatoire des Sciences de l'Univers de Rennes using the Autoscan (C) software (on manual mode) on a Zeiss M1 microscope, with a magnification of 1250 under dry objectives. All ages are central ages and errors are quoted at $2 \sigma$ (e.g. Galbraith \& Laslett, 1993 ; Galbraith, 2005). The Dpar kinetic parameter was measured on all 
to the generally poor quality of the apatite crystals, not enough confined track lengths could be measured in each sample to allow robust thermal modelling. Data are reported in Table 1.

\subsection{Data}

Samples selected for AFT analysis are from both metamorphic and detrital rocks.

\section{2.a. Metamorphic samples}

Sample CG03 comes from the shales of the Triassic-Jurassic marble-schist unit included in the Pelagonian Fault. Eleven grains give a central age of $38.8 \pm 6.3 \mathrm{Ma}$. Sample CG08 comes from the same unit further north and has a central age of $30.9 \pm 4.7$ Ma based on 22 crystals (Fig. 8A). Considering the high $\mathrm{P}\left(\chi^{2}\right)$ value $(\sim 100 \%)$, the individual apatite ages seem to be regrouped in one main age population ranging from Palaeocene to Oligocene. Three early/middle Miocene ages mark younger ages of this group in CG08 (Fig. 8B). The chlorite schists sample CG11 in the Pelagonian Paleozoic basement yields a central age of $19.3 \pm 2.0$ Ma based on 19 analysed crystals. As suggested by the relatively low $\mathrm{P}(\chi 2)$ of $38 \%$, this sample shows two distinct age groups, one Oligocene the other early to middle Miocene (grey and red arrow Fig. 8C). Sample CG13 is a gneiss from the Pelagonian basement, comparable with CG11 but with potentially higher metamorphic grade. Only seven apatite crystals could be dated. The individual ages range between 25 and 45 Ma with a central age of 30.8 $\pm 7.2 \mathrm{Ma}$ (Fig. $8 \mathrm{D}$ ).

\section{2.b. Detrital apatite samples}

These samples provided more apatite crystals compare to the metamorphic samples. CG14 was collected from the Pindos Flysch. The analysis of 50 crystals provided a central age of $36.4 \pm 3.1 \mathrm{Ma}$. The individual ages are largely scattered between 90 and $12 \mathrm{Ma}$. The sample displays three age groups: 1/ an older group corresponding to Palaeocene-early Eocene times, 2/ a Mid-Eocene to Oligocene group and 3/ a younger early Miocene group (Fig. 8E). Sample CG16, also collected in the Pindos Flysch gives a younger central age of $30.7 \pm 4.7$ Ma based on 23 crystals. Individual ages are scattered between 139 and 10Ma (Fig. 8F). However, two groups are distinguished with a respective age population ranging from Cretaceous to early Eocene and Oligocene to middle Miocene. The second group is mainly composed of Miocene ages.

\subsection{AFT data interpretation}

Samples CG03 and CG08 from the lower Mesozoic series have clearly been reset after the sediment deposition but the large spread in individual ages associated with late Eocene - Oligocene central ages suggests slow exhumation initiated during that period (Fig. 8). Sample CG11, collected in the same unit as CG13, also displays few Oligocene ages but the early Miocene central age suggests either a later 
exhumation or an exhumation from a deeper level. The second hypothesis would be consistent with the stratigraphic position of sample CG11 situated below sample CG13. The stratigraphic age of the sediments that formed samples CG14 and CG16 is assumed to be between 70 and $45 \mathrm{Ma}$ (Faupl et al., 1998, 2007).

The occurrence of individual ages much older than the deposition age (especially in sample CG16) suggests, at most, partial post-depositional resetting within the apatite partial annealing zone (Fig. 8). The sediments were therefore buried to a depth of less than $4 \mathrm{~km}$, allowing sufficient annealing to rejuvenate some of the apatite crystals, the degree of annealing probably depending on chemical composition (Barbarand et al., 2003). The Oligocene central ages obtained for those two samples again suggest exhumation during that period, implying a regional event.

The youngest age groups observed in samples CG11, CG14, CG16 and possibly CG08 could be interpreted as a final exhumation phase dated at the minimum from the early Miocene (CG14) to middle Miocene (CG08, CG11 and CG16, red arrow - Fig. 8).

Our AFT data show, in the majority of samples, an Oligocene exhumation event and a second early to middle Miocene exhumation phase (arrows in Fig. 8 and Fig. 9). The associated large dispersion of the AFT individual ages suggests a phase of slow exhumation of the Pelagonian rocks in Central Greece during the Oligocene. The middle Miocene AFT ages recorded in our samples are strongly related to NW-striking high-angle normal faults. The locations of samples CG11, CG16 and potentially CG14 in the footwall of NW-striking normal faults (Fig. 9A), highlight local exhumation during a relatively fast middle Miocene event (compared to the Oligocene phase). This feature suggests a middle Miocene activity of the NW-striking normal faults, as already suggested by our structural analysis.

\section{Discussion}

\subsection{Differential amount of exhumation across the Pelagonian fault}

Our new AFT data allow, for the first time, a regional-scale comparison between the Cycladic unit and the Pelagonian unit (Fig. 9A). In Central Greece, our AFT data show a clustering in age around the Oligocene. Published AFT, zircon fission track (ZFT) and (U-Th)/He on zircon data in northern Greece (Hejl et al., 1999, 2008; Most, 2003; Thomson et al., 2009; Vamvaka et al., 2010; Coutand et al., 2014; Schenker et al., 2015) also presented numerous ages in the early-Miocene, Oligocene and older ages, suggesting a regional exhumation event at minimum before 16Ma (Fig. 9B). The Cyclades also recorded an Oligocene exhumation (with Ar/Ar ages, see synthesis of thermochronoloy in Philippon et al., 2012) inducing a widespread exhumation throughout the Aegean domain at this time. However, in the Cyclades, the low-temperature thermochronology ages (ZFT, AFT, U-Th/He on zircon and Apatite Hejl et al., 2002, 2008; Ring et al., 2003, 2007; Brichau et al., 2006, 2008; Seward et al., 2009; Berger et al., 2013; Soukis and Stockli, 2013; Seman, 2016; Grasemann et al., 2018; Schneider et al., 2018) are much younger and concentrated in the late/middle Miocene, suggesting faster exhumation during this 
period (Fig. 9A and B). This Miocene cluster of low-temperature thermochronology ages marks the large amount of extension/exhumation recorded in the Cyclades, as exemplified by the activity of several low-angle normal fault/detachment systems (Avigad and Garfunkel, 1989; Gautier et al., 1993; Tschegg and Grasemann, 2009; Jolivet et al., 2010b; Krohe et al., 2010; Iglseder et al., 2011; Grasemann et al., 2012, 2018). In Central Greece, the young AFT ages are concentrated on samples close to some high-angle normal faults (see our data and data from Coutand et al., 2014 in the Sporades), contrastingly suggesting a limited amount of exhumation/extension during Miocene time. Furthermore, scattered AFT ages between the Paleogene/Oligocene to late-Miocene could suggest slow exhumation of the Pelagonian rocks or heterogenous amount of exhumation at regional scale. This highlights a major difference in the amount of exhumation and hence of crustal extension between Central Greece and the Cyclades during the Miocene. This feature is also exemplified at first order by the unroofing of the Cycladic unit, structurally below Pelagonia (see nappe stack discussion in our introduction and in Fig. 1). We suggest that the Pelagonian strike-slip fault accommodates lateral differences in the amount of extension during the Miocene. This is accompanied by a large amount of extension accommodated by detachment faults in the Cyclades, and much lower amount of extension in Central Greece mainly accommodated by high-angle normal faults (Figs. 2 and 9).

\subsection{Central Greece faulting activity and middle Miocene basins}

Our structural data show that in the middle Miocene, syn-tectonics basin sedimentation is coeval with NW-striking normal faults and NE-striking dextral strike-slip activities (Fig. 2). Limni basin deposition (North Evvia) is controlled by NW-striking normal faults (with dip slip motion). AFT data on samples in the footwall of these normal faults show local middle Miocene ages, suggesting middle Miocene cooling. Our structural data are consistent with the formation of the Limni basin during NE-SW extension (Fig. 5) in Miocene time controlled by NW-striking normal faults, as already suggested by Mettos et al. (1991), (1992). The Kymi basin deposition is mainly controlled by the dextral strike-slip Pelagonian Fault corridor (Fig. 2), locally associated with NW-striking normal faults. Previous studies have already suggested strike-slip activity along the Pelagonian Fault during the middle Miocene but in a transpressive context (Kokkalas, 2001; Xypolias et al., 2003; Kokkalas et al., 2006). Our stress tensor calculation on the Pelagonian fault implies an E-W direction of compression (Fig. 7) that is consistent with compressional structures described previously (Kokkalas, 2001; Xypolias et al., 2003) but does not require a transpressional context. The combination of our structural data from Limni and Kymi basins suggests coeval middle Miocene activity of the NW-striking normal faults and the NE-striking strike-slip faults, indicating instead a transtensive regime during Kymi basin deposition. At large scale, E-W shortening is also highlighted by the presence of large open folds (i.e. Almyropotamos fold Evvia island, Penteli - North of Athens and Ymitos mountain - East of Athens, see map in Bradley, 2012) with the axis evolving from N-S to NE-SW close to the Pelagonian dextral strike-slip fault (Kokkalas, 2001; Xypolias et al., 2003). In summary, our structural data show that the middle Miocene 
582

583

584

585

586

587

588

589

590

591

592

593

594

595

596

597

598

599

600

601

602

603

604

605

606

607

608

609

610

611

612

613

614

615

616

617

tectonics of Central Greece is marked by the coeval activity of NE-striking dextral faults and NWstriking normal faults, with spatial strain partitioning: NE-striking faults mainly inside the Pelagonian fault strike-slip corridor, associated in its vicinity with N/NE-S/SW folds, and away from this corridor, extension with NW-striking normal faults (Fig. 2). At regional scale, the existence of strike-slip activity in middle Miocene times is also independently suggested by the presence of syn-kinematics structures in middle Miocene plutons in the Cyclades (Walcott and White, 1998; Kokkalas and Aydin, 2013), although their fault kinematics are still debated (van Hinsbergen and Schmid, 2012; Malandri et al., 2017).

Our structural data show that the Plio-Quaternary is marked by E-striking normal faults mainly developed inside pre-existing NW-striking faults. Kokkalas (2010) describes the consistently close link between NW-striking and E-striking normal faults, with E-W relay zones inside major NW fault zones. This interplay defines a complex fault zone growth and propagation, likely explaining the major fault striking NW in Central Greece. This likely explains NW-striking oblique rift systems in Central Greece (Evvia and Corinth, Fig 2) associated with E-striking normal faults. These tectonics structures control Plio-Quaternary basin formation.

\subsection{Stress regimes in Mid Miocene and Plio Quaternary times.}

Stress tensor calculations show that the Plio-Quaternary N-S extension is associated with E-striking normal faults and oblique reactivation of NW-striking normal faults (Fig. 5). These findings are consistent with present-day seismic activity and focal mechanisms showing coeval E-striking normal faulting, sinistral normal activity along these NW-striking faults (Kiratzi and Louvari, 2003; Ganas et al., 2016), as well as N-S strain rate directions inferred from GPS data (Davies et al., 1997; Reilinger et al., 2006; Hollenstein et al., 2008; Pérouse et al., 2012). Similar conclusions were proposed further North, close to the Olympus Mount (e.g. Kozani normal fault - Schenker et al., 2015).

Because the present-day seismic activity shows also coeval NE-striking dextral strike-slip (e.g. North Anatolian Fault to the North of the studied area) and E-striking normal faulting in Greece, (e.g. Corinth and Evvia rifts), we tested the compatibility between our measured NE-striking dextral faults (Pelagonian fault, family 4) and the combination of E-striking normal faults (family 1) and NW-striking strike-slip faults (family 2) by inverting them together. The combination of these three families yielded $\mathrm{T}_{124}$ stress tensor (supplementary materials Fig. S4, Table ST1) in the wrench tectonics regime (Fig. 10 and supplementary material Table ST2). Even though the solution quality is statistically good (Table ST2), it comes into sight that, whereas it accounts for most data from family 4 , it poorly accounts for data from families 1 and 2 (supplementary material Fig. S7). It thus appears more like the result of extracting a phase, similar to $\mathrm{T}_{4}$ from a multiphase family, rather than a phase explaining all three families 1, 2 and 4 together. The combination of family 4 with families and 1 and 2 thus fails to demonstrate compatibility and rather highlights heterogeneity. The poor compatibility of family 4 
618 (dextral strike-slip) with the combination of families 1 and 2 (normal and sinistral faults) is, in fact,

619 consistent with the total absence of dextral strike-slip faults in Central Greece, a region only 620 characterized by Plio-Quaternary extension (Corinth and Evvia rifts, Stefatos et al., 2002; Lykousis et 621 al., 2007; Bell et al., 2009). This suggests a Plio-Quaternary strain partitioning with normal faulting in 622 Central Greece and dextral strike-slip faulting in Northern Greece (North Anatolian Trough and North 623 Anatolian Fault). This furthermore suggests the absence of a clear link between the NAF and 624 Corinth/Evvia rift systems, at variance with Armijo et al. (1996).

625 Our structural observations suggest in contrast a coeval activity of NW-striking normal faults (family 626 3) and NE-striking strike-slip faults (family 4) during middle Miocene. We thus tested the stress 627 compatibility between these two families by inverting them together. This combination yields $\mathrm{T}_{34}$ stress 628 tensor in the wrench tectonics regime with vertical $\mathrm{s}_{2}$ and $\mathrm{r} 0=0.14$, thus close to the transition with the 629 extensional regime (Figs. 10A and 10B and supplementary material Table ST1). This solution accounts 630 for most data of families 3 and 4 (Nexp15=27, supplementary materials Table ST2; Fig S5) with a 631 quality equivalent to that of $\mathrm{T}_{4}$, thus supporting compatibility between these two families. Therefore, $632 \mathrm{~T}_{34}$ tensor suggests a wrench middle Miocene tectonics regime activating both normal and dextral faults 633 (Figs. 10B and E).

634 Palaeomagnetic data support mean value of $\sim 30^{\circ}$ of rotation (Horner and Freeman, 1983; Kissel et al., 635 1986, 2003; Duermeijer, 2000; van Hinsbergen et al., 2005, 2006; Bradley et al., 2013) during Miocene 636 times, with a rotation pole close to Scutari-Pec. NW-striking normal faults, formed before or during 637 such rotation, were therefore rotated during Miocene times. In contrast, NE-striking dextral fault have 638 undergone little if any rotation because they are sub-parallel to the small Eulerian circle. We, therefore, 639 suggest that NE-striking faults accommodated the clockwise rotation, which is consistent with their 640 dextral movement (inset of Fig. 11B). We, therefore, applied a $30^{\circ}$ counter-clockwise vertical axis 641 rotation to the NW-striking normal faults (family 3 ) to restore them in their Miocene original position 642 (family $3 \mathrm{r}$ - after a backrotation of $30^{\circ}$, Fig. 10C). We then combined this restored family $3 \mathrm{r}$ (became 643 E-striking normal faults) with the NE strike-slip faults (family 4) and inverted this combination. This 644 yielded $\mathrm{T}_{3 \mathrm{r} 4}$ in the wrench tectonics regime (Figs. 10D and $\mathrm{E}$ and supplementary material S6). This 645 solution is similar to $\mathrm{T}_{34}$, with a similar quality, also with a horizontal maximum principal stress 646 direction, $\mathrm{s}_{1}$, that is now close to E-W (supplementary materials Table ST1 and ST2).

648 5.4. Central Greece tectonics since Miocene times

649 On these bases, we propose the following evolution of Central Greece tectonics since middle Miocene 650 times. In the middle Miocene, the co-existence of NE-striking dextral strike-slip and E-striking normal 651 faults (i.e. back-rotated present-day NW-striking faults - Fig. 11A) corresponds to a wrench tectonics 652 regime with an almost N-S extension and E-W compression ( $\mathrm{T}_{3 \mathrm{r} 4}$ tensor - Fig. 11A). We propose that 653 the E-W compression is related to westward extrusion of Anatolia that most probably started during the 654 middle Miocene in a broad zone of deformation (North Anatolian Shear Zone, Şengör et al., 1979, 
2005). Furthermore, the existence of calcite gouge in the NAF with middle Miocene ages supports this hypothesis (Nuriel et al., 2019). This E-W compression is furthermore consistent with middle Miocene transpressional structures affecting molasse basins and granitic intrusions (Kokkalas et al., 2006; Kokkalas and Aydin, 2013). The extensional direction is orthogonal to the middle/late Miocene position of the Hellenic trench, suggesting that extension was controlled by Aegean trench retreat (Papanikolaou \& Royden, 2007; Royden \& Papanikolaou, 2011). The observed spatial distribution of deformation, with strike-slip corridors localising shortening (with folds) and pure extensional structures away from these corridors, may be controlled by tectonics inheritance, as the Pelagonian strike-slip corridor is located in the main contact between Adria/Pindos and Pelagonia.

The progressive trench curvature during rollback implies block rotation, likely accommodated by the NE-striking dextral faults (Fig. 11B). Normal faults rotated together with $\mathrm{s}_{3}$ which became NE-SW $\left(\mathrm{T}_{34}\right.$ tensor - Fig. 11B). This progressive rotation can explain the widespread distribution of NW normal fault strikes, as shown in our data (Fig 6 with NW- normal faults striking from N110 to N150). Compression related to Anatolia extrusion remains EW during Miocene times and is accommodated in NE-striking dextral faults (tensor $\mathrm{T}_{4}$-Fig. 7; and Fig. 11A and B). Our AFT and structural data show that the Pelagonian fault acted as major dextral strike-slip fault during middle Miocene. The Pelagonian fault accommodated not only EW compression but also accomodated lateral different amounts and styles of continental extension during trench curvature and block rotation: a large and younger amount of extension in the Cyclades/South Evvia/Attica accommodated by detachment faulting (Avigad and Garfunkel, 1989; Gautier et al., 1993; Liati et al., 2009 ; Tschegg and Grasemann, 2009 ; Jolivet et al., 2010a; Krohe et al., 2010; Iglseder et al., 2011; Grasemann et al., 2012, 2018 ; Scheffer et al., 2016; Coleman et al., 2019) and less extension in Central Greece (north of the Pelagonian fault) mainly accommodated by high-angle normal faults (Fig. 11A and B).

During the Plio-Quaternary, Central Greece evolved into a pure extensional tectonics regime, with almost radial extension and no more E-W shortening (tensor $\mathrm{T}_{12}$ - Figs. 5 and 10E and 11C). This implies that westward extrusion of Anatolia became fully accommodated by the North Anatolian Fault (NAF, as also suggested by Armijo et al., 1996; Reilinger et al., 1997) leading to the formation of the Anatolia/Aegean microplate. The middle Miocene normal faults were used to define NW-striking oblique rifts, with newly formed E-striking normal faults (Fig. 11C).

Our study suggests therefore that the Corinth and Evvia rifts are not opening in response to westward propagation of the NAF (Armijo et al., 1996) but are instead related to progressive strain localisation at lithospheric scale controlled by both a change in the direction of extension and the presence of inherited structures. This change in the direction of extension from NE-SW to N-S during the Plio-Quaternary cannot be explained by the progressive trench curvature and block rotation during trench retreat. It can be more likely related to slab deformation at depth, as exemplified by the formation of the Kephalonia strike-slip fault (Evangelidis, 2017; Bocchini et al., 2018). 


\section{Conclusions}

693

694 Based on new structural data, stress tensor analysis and AFT data in Central Greece, we draw the 695 following conclusions

696 - middle Miocene basins in Central Greece are controlled by both NW-striking normal faults and NE-

697 striking dextral strike-slip faults. The Pelagonian fault that limits Pelagonia-derived rocks to the north 698 from Adria-derived rocks to the south is an example of such dextral strike-slip active during the middle 699 Miocene.

700 - Apatite Fission Track data constrain middle Miocene local exhumation near NW-striking high-angle normal faults in Central Greece, confirming their middle Miocene activity.

- New Apatite Fission Track data for Central Greece suggest a significant difference in the amount of exhumation between Central Greece and the Cyclades. This difference in the amount of exhumation/exhumation is found to be accommodated by the Pelagonian dextral strike-slip fault.

-The co-existence of NE-striking dextral strike-slip and NW-striking normal faults during the middle Miocene is associated with an almost N-S extension related to trench retreat and an E-W compression related to westward extrusion of Anatolia.

-The progressive trench curvature during slab rollback implies a progressive rotation of NW-striking normal faults. This rotation is proposed to be accommodated in Central Greece by the Pelagonian fault.

710 - During the Plio-Quaternary, a change in extensional direction from NE-SW to N-S implies the

711 formation of E-W normal faults inside NW-striking fault zone, defining oblique rift systems.

712

713 Acknowledgements

715 This work was initiated by fruit-full discussion in the field with Jean-Pierre Brun in October 2017.

716 Cyprien Astoury (Géosciences Montpellier) is thanked for his help in preparing samples (grinding and 717 separation). Our work has received funding from the European Union's EU Framework Programme 718 for Research and Innovation Horizon 2020 under Grant Agreement No. 674899. The Free GMT 719 software (Wessel and Smith, 1991) was used for some illustrations. Additional datasets for this research 720 were acquired from the literature, included datasets for Pelagonian dating: Hejl et al., 1999, 2008; Most, 721 2003; Thomson et al., 2009; Vamvaka et al., 2010; Coutand et al., 2014; Schenker et al., 2015; for the 722 Cyclades/South Evvia/ Attica datation: Hejl et al., 2002, 2008; Ring et al., 2003, 2007; Brichau et al., 723 2006, 2008; Seward et al., 2009; Berger et al., 2013; Soukis and Stockli, 2013; Seman, 2016; Grasemann 724 et al., 2018; Schneider et al., 2018 and for GPS data (Hollenstein et al., 2008). Readers can access our structural and thermochronology data from the text, tables and figures, as well as our complete dataset on https://hal.archives-ouvertes.fr/hal-03175867 . 


\section{References}

Anderson, E. M. (1905). The dynamics of faulting, Transactions of the Edinburgh Geological Society,

Angelier, J. (1984). Tectonic analysis of fault slip data sets, J. Geophys. Res., 89(B7), 5835-5848, doi:10.1029/JB089iB07p05835.

Armijo, R., Carey, E., and Cisternas, A. (1982). The inverse problem in microtectonics and the separation of tectonic phases, Tectonophysics, 82, 145-160.

Armijo, R., Meyer, B., King, G.C.P., Rigo, A., Papanastassiou, D. (1996). Quaternary evolution of the

Corinth Rift and its implications for the Late Cenozoic evolution of the Aegean. Geophys. J. Int. 126,

Armijo, R., Meyer, B., Hubert, A., Barka, A. (1999). Westward propagation of the North Anatolian fault into the northern Aegean: Timing and kinematics. Geology 27, 267. https://doi.org/10.1130/00917613(1999)027<0267:WPOTNA>2.3.CO;2

Armijo, R., Flerit, F., King, G., Meyer, B. (2004). Linear elastic fracture mechanics explains the past and present evolution of the Aegean. Earth Planet. Sci. Lett. 217, 85-95. https://doi.org/10.1016/S0012$821 \mathrm{X}(03) 00590-9$

Aubouin, J. (1959). Contribution à l'étude géologique de la Grèce septentrionale: les confins de

Hellénique, 10, 1-483. Paris.

Aubouin, J., Dercourt, J. (1965). Sur la géologie de l'Egee; regard sur la Crete (Grèce). Bull. Société

Géologique Fr. 7, 787-821.

Avigad, D., Garfunkel, Z. (1989). Low-angle faults above and below a blueschist belt?Tinos Island, 
Bell, R.E., McNeill, L.C., Bull, J.M., Henstock, T.J., Collier, R.E.L., Leeder, M.R. (2009). Fault architecture, basin structure and evolution of the Gulf of Corinth Rift, central Greece. Basin Res. 21, 824-855. https://doi.org/10.1111/j.1365-2117.2009.00401.x

Berger, A., Schneider, D.A., Grasemann, B., Stockli, D. (2013). Footwall mineralization during Late Miocene extension along the West Cycladic Detachment System, Lavrion, Greece. Terra Nova 25, 181191. https://doi.org/10.1111/ter.12016

773

774

775

776

777

778

779

780

781

782

783

784

785

786

787

788

789

790

791

792

793

794

795

796

797

798

799

800

801

Bessiere, E., Rabillard, A., Précigout, J., Arbaret, L., Jolivet, L., Augier, R., Menant, A., Mansard, N. (2018). Strain Localization Within a Syntectonic Intrusion in a Back-Arc Extensional Context: The Naxos Monzogranite (Greece): STRAIN LOCALIZATION IN THE NAXOS PLUTON. Tectonics 37, 558-587. https://doi.org/10.1002/2017TC004801

Bocchini, G.M., Brüstle, A., Becker, D., Meier, T., van Keken, P.E., Ruscic, M., Papadopoulos, G.A., Rische, M., Friederich, W. (2018). Tearing, segmentation, and backstepping of subduction in the Aegean: New insights from seismicity. Tectonophysics 734-735, 96-118. https://doi.org/10.1016/j.tecto.2018.04.002

Bonneau, M. (1984). Correlation of the Hellenide nappes in the south-east Aegean and their tectonic reconstruction. Geol. Soc. Lond. Spec. Publ. 17, 517-527. https://doi.org/10.1144/GSL.SP.1984.017.01.38

Bono, A.D., Stampfli, G.M., Martini, R., Vachard, D. (1998). ANNALES GÉOLOGIQUES DES PAYS HELLÉNIQUES 17.

Bornovas, J., Rondogianni-Tsiambaou, T. (1983). Geological map of Greece, 1: 500000.

Bott, M. H. P. (1959). The mechanics of oblique slip faulting, Geological Magazine, 96(2), 109-117, doi:10.1017/S0016756800059987.

Bradley, K.E. (2012). The roof of the Cyclades: A structural, stratigraphic, and paleomagnetic study of Neogene extensional tectonics in Central Greece (Doctoral dissertation). Massachusetts Institute of Technology.

Bradley, K.E., Vassilakis, E., Hosa, A., Weiss, B.P. (2013). Segmentation of the Hellenides recorded by Pliocene initiation of clockwise block rotation in Central Greece. Earth Planet. Sci. Lett. 362, 6-19. https://doi.org/10.1016/j.eps1.2012.11.043 
803 Brichau, S., Ring, U., Ketcham, R. A., Carter, A., Stockli, D., \& Brunel, M. (2006). Constraining the 804 long-term evolution of the slip rate for a major extensional fault system in the central Aegean, Greece, 805 using thermochronology. Earth and Planetary Science Letters, 241(1-2), 293-306. 806 https://doi.org/10.1016/j.eps1.2005.09.065

807

808 Brichau, S., Ring, U., Carter, A., Bolhar, R., Monié, P., Stockli, D., Brunel, M. (2008). Timing, slip 809 rate, displacement and cooling history of the Mykonos detachment footwall, Cyclades, Greece, and 810 implications for the opening of the Aegean Sea basin. J. Geol. Soc. 165, 263-277. 811 https://doi.org/10.1144/0016-76492006-145

812

813 Brun, J-P., Faccenna, C. (2008). Exhumation of high-pressure rocks driven by slab rollback. Earth 814 Planet. Sci. Lett. 272, 1-7. https://doi.org/10.1016/j.epsl.2008.02.038

815

816 Brun, J-P., Sokoutis, D. (2018). Core Complex Segmentation in North Aegean, A Dynamic View. 817 Tectonics 37, 1797-1830. https://doi.org/10.1029/2017TC004939

819 Brun, J-P., Faccenna, C., Gueydan, F., Sokoutis, D., Philippon, M., Kydonakis, K., Gorini, C. (2016). 820 The two-stage Aegean extension, from localized to distributed, a result of slab rollback acceleration. 821 Can. J. Earth Sci. 53, 1142-1157. https://doi.org/10.1139/cjes-2015-0203

822

823 Burg, J-P., B. Célérier, N. M. Chaudhry, M. Ghazanfar, F. Gnehm, Schnellmann, M. (2005), Fault 824 analysis and paleostress evolution in large strain regions: methodological and geological discussion of 825 the southeastern Himalayan fold-and-thrust belt in Pakistan, Journal of Asian Earth Sciences, 24(4), 826445 - 467, doi:10.1016/j.jseaes.2003.12.008.

827 Célérier, B. (1995). Tectonic regime and slip orientation of reactivated faults, Geophysical Journal 828 International, 121(1), 143-191, doi:10.1111/j.1365-246X.1995.tb03517.x \& 10.1111/j.1365829 246X.1995.tb07021.x.

830

831 Célérier, B. (2020). Fsa: Fault \& Stress Analysis software, version 37.5, http://www.celerier.gm.univ832 montp2.fr/software/dcmt/fsa/fsa.html.

833

834 Clift, P.D., Dixon, J.E. (1998). Jurassic ridge collapse, subduction initiation and ophiolite obduction in 835 the southern Greek Tethys. Eclogae Geol. Helvetiae 123-138.

837 Coleman, M., et al. (2019). "Along-strike consistency of an extensional detachment system, West 838 Cyclades, Greece." Terra Nova 31(3): 220-233. 
840 Coutand, I., Walsh, M., Louis, B., Chanier, F., Ferrière, J., Reynaud, J.-Y. (2014). Neogene upper-

841 crustal cooling of the Olympus range (northern Aegean): major role of Hellenic back-arc extension over

842 propagation of the North Anatolia Fault Zone. Terra Nova 26, 287-297.

843 https://doi.org/10.1111/ter.12099

844

845 Cundy, A.B., Gaki-Papanastassiou, K., Papanastassiou, D., Maroukian, H., Frogley, M.R., Cane, T.

846 (2010). Geological and geomorphological evidence of recent coastal uplift along a major Hellenic

847 normal fault system (the Kamena Vourla fault zone, NW Evoikos Gulf, Greece). Mar. Geol. 271, 156-

848 164. https://doi.org/10.1016/j.margeo.2010.02.009

849

850 Davies, R., England, P., Parsons, B., Billiris, H., Paradissis, D., Veis, G. (1997). Geodetic strain of

851 Greece in the interval 1892-1992. J. Geophys. Res. Solid Earth 102, 24571-24588.

852 https://doi.org/10.1029/97JB01644

853

854 Diamantopoulos, A., Krohe, A., Mposkos, E. (2009). Kinematics of conjugate shear zones, 855 displacement partitioning and fragmentation of the upper rigid crust during denudation of high-P rocks 856 (Pelagonian and Sub-Pelagonian Zones, Greece). Tectonophysics 473, 84-98. 857 https://doi.org/10.1016/j.tecto.2008.05.028

858

859 Doutsos, T., Pe-Piper, G., Boronkay, K., Koukouvelas, I. (1993). Kinematics of the central Hellenides.

860 Tectonics 12, 936-953. https://doi.org/10.1029/93TC00108

861

862 Doutsos, T., Koukouvelas, I.K., Xypolias, P. (2006). A new orogenic model for the External Hellenides.

863 Geol. Soc. Lond. Spec. Publ. 260, 507-520. https://doi.org/10.1144/GSL.SP.2006.260.01.21

864

865 Duermeijer, C. (2000). Neogene evolution of the Aegean arc: paleomagnetic and geodetic evidence for 866 a rapid and young rotation phase. Earth Planet. Sci. Lett. 176, 509-525. https://doi.org/10.1016/S0012$867 \quad 821 \mathrm{X}(00) 00023-6$

868

869 Dunkl, I. (2002). Tracnkkey: a Windows program for calculation and graphical presentation of fission track data. Comput. Geosc. 28, 3-12. https://doi.org/10.1016/S0098-3004(01)00024-3

872 Etchecopar, A., G. Vasseur, Daignieres, M. (1981). An inverse problem in microtectonics for the 873 determination of stress tensors from fault striation analysis, Journal of Structural Geology, 3(1), 51-65, 874 doi:10.1016/0191-8141(81)90056-0. 
876 Evangelidis, C.P. (2017). Seismic anisotropy in the Hellenic subduction zone: Effects of slab

877 segmentation and subslab mantle flow. Earth Planet. Sci. Lett. 480, 97-106.

878 https://doi.org/10.1016/j.eps1.2017.10.003

879

880 Faccenna, C., Jolivet, L., Piromallo, C., Morelli, A. (2003). Subduction and the depth of convection in

881 the Mediterranean mantle: CONVECTION DEPTH IN THE MEDITERRANEAN MANTLE. J.

882 Geophys. Res. Solid Earth 108. https://doi.org/10.1029/2001JB001690

883

884 Faupl, P., Pavlopoulos, A., Migiros, G. (1998). On the provenance of flysch deposits in the External

885 Hellenides of mainland Greece: results from heavy mineral studies. Geol. Mag. 135, 421-442.

886 https://doi.org/10.1017/S001675689800870X

887

888 Faupl, P., Pavlopoulos, A., Migiros, G. (2007). THE PALEOGENE HISTORY OF THE 889 PELAGONIAN ZONE S. L. (HELLENIDES, GREECE): HEAVY MINERAL STUDY FROM 890 TERRIGENOUS FLYSCH SEDIMENTS 10.

891

892 Flerit, F., Armijo, R., King, G., Meyer, B. (2004). The mechanical interaction between the propagating 893 North Anatolian Fault and the back-arc extension in the Aegean. Earth Planet. Sci. Lett. 224, 347-362. 894 https://doi.org/10.1016/j.eps1.2004.05.028

895

896 Forster, M.A., Lister, G.S. (1999). Detachment faults in the Aegean core complex of Ios, Cyclades, 897 Greece. Geol. Soc. Lond. Spec. Publ. 154, 305-323. https://doi.org/10.1144/GSL.SP.1999.154.01.14

898

899 Galbraith, R.F. (1990). The radial plot: graphical assessment of spread in ages. Nucl. Tracks Radiat. 900 Meas. 17, 207-214. https://doi.org/10.1016/1359-0189(90)90036-W

901

902 Galbraith, R.F. (2005). The Statistics for Fission Track Analysis. Boca Raton, Florida, Chapman \& 903 Hall/CRC, 240.

904

905 Galbraith, R.F., Laslett, G.M. (1993). Statistical models for mixed fission track ages. Nucl. Tracks

906 Radiat. Meas. 21, 459-470. https://doi.org/10.1016/1359-0189(93)90185-C

907

908 Ganas, A., Mouzakiotis, E., Moshou, A., Karastathis, V. (2016). Left-lateral shear inside the North Gulf 909 of Evia Rift, Central Greece, evidenced by relocated earthquake sequences and moment tensor 910 inversion. Tectonophysics 682, 237-248. https://doi.org/10.1016/j.tecto.2016.05.031

912 Gautier, P., \& Brun, J-P. (1994). Ductile crust exhumation and extensional detachments in the central 
913 Aegean (Cyclades and Evvia Islands). Geodinamica, 7(2), 57-85.

914

915 Gautier, P., Brun, J-P., Jolivet, L. (1993). Structure and kinematics of Upper Cenozoic extensional

916 detachment on Naxos and Paros (Cyclades Islands, Greece). Tectonics 12, 1180-1194.

917 https://doi.org/10.1029/93TC01131

918

919 Gleadow, A.J.W., Duddy, I.R., 1981. A natural long-term track annealing experiment for apatite. Nucl.

920 Tracks 5, 169-174. https://doi.org/10.1016/0191-278X(81)90039-1

921

922 Goldsworthy, M., Jackson, J., Haines, J. (2002). The continuity of active fault systems in Greece: Fault 923 continuity in Greece. Geophys. J. Int. 148, 596-618. https://doi.org/10.1046/j.1365-246X.2002.01609.x 924

925 Grasemann, B., Schneider, D.A., Stöckli, D.F., Iglseder, C. (2012). Miocene bivergent crustal extension

926 in the Aegean: Evidence from the western Cyclades (Greece). Lithosphere 4, 23-39. 927 https://doi.org/10.1130/L164.1

928

929 Grasemann, B., Huet, B., Schneider, D.A., Rice, A.H.N., Lemonnier, N., Tschegg, C. (2018). Miocene 930 postorogenic extension of the Eocene synorogenic imbricated Hellenic subduction channel: New 931 constraints from Milos (Cyclades, Greece). GSA Bull. 130, 238-262. https://doi.org/10.1130/B31731.1 932

933 Green, P. F. (1985). Comparison of zeta calibration baselines for fission-track dating of apatite, zircon

934 and sphene. Chemical Geology: Isotope Geoscience section, 58(1-2), 1-22. 935 https://doi.org/10.1016/0168-9622(85)90023-5

936

937 Hejl, E., Riedl, H., Weingartner, H. (1999). Cretaceous palaeokarst and Cenozoic erosion of the North 938 Sporades (Greece): Results from geomorphological studies and fission-track analysis. Mitteilungen 939 Österr. Geol. Ges. Wien 90, 67-82.

941 Hejl, E., Riedl, H., Weingartner, H. (2002). Post-plutonic unroofing and morphogenesis of the Attic942 Cycladic complex (Aegea, Greece). Tectonophysics 349, 37-56. https://doi.org/10.1016/S0040943 1951(02)00045-8

944

945 Hejl, E., de Grave, J., Riedl, H., Weingartner, H., Van den haute, P. (2008). Fission-track 946 thermochronology of the Middle Aegean Island Bridge implications for Neogene geomorphology and 947 palaeogeography. Z. Dtsch. Ges. Für Geowiss. 159, 495-512. https://doi.org/10.1127/1860$948 \quad 1804 / 2008 / 0159-0495$ 
950 Heuberger, S., B. Célérier, J. P. Burg, N. M. Chaudhry, H. Dawood, and Hussain, S. (2010), Paleostress

951 regimes from brittle structures of the Karakoram-Kohistan suture zone and surrounding areas of NW

952 Pakistan, Journal of Asian Earth Sciences, 38(6), 307-335, doi:10.1016/j.jseaes.2010.01.004.

953

954 Hollenstein, Ch., Müller, M.D., Geiger, A., Kahle, H.-G. (2008). Crustal motion and deformation in 955 Greece from a decade of GPS measurements, 1993-2003. Tectonophysics 449, 17-40. 956 https://doi.org/10.1016/j.tecto.2007.12.006

957

958 Horner, F., Freeman, R. (1983). Palaeomagnetic evidence from pelagic limestones for clockwise 959 rotation of the Ionian zone, western Greece. Tectonophysics 98, 11-27. https://doi.org/10.1016/0040960 1951(83)90208-1

961

962 Hubert-Ferrari, A., Armijo, R., King, G., Meyer, B., Barka, A. (2002). Morphology, displacement, and 963 slip rates along the North Anatolian Fault, Turkey: THE NORTH ANATOLIAN FAULT. J. Geophys. 964 Res. Solid Earth 107, ETG 9-1-ETG 9-33. https://doi.org/10.1029/2001JB000393

965

966 Hubert-Ferrari, A., King, G., Manighetti, I., Armijo, R., Meyer, B., Tapponnier, P. (2003). Long-term 967 elasticity in the continental lithosphere; modelling the Aden Ridge propagation and the Anatolian 968 extrusion process. Geophys. J. Int. 153, 111-132. https://doi.org/10.1046/j.1365-246X.2003.01872.x

970 Hurford, A.J. (1990). Standardization of fission track dating calibration: Recommendation by the 971 Fission Track Working Group of the I.U.G.S. Subcommission on Geochronology. Chem. Geol. Isot. 972 Geosci. Sect. 80, 171-178. https://doi.org/10.1016/0168-9622(90)90025-8

973

974 Hurford, A.J., Green, P.F. (1982). A users' guide to fission track dating calibration. Earth Planet. Sci. 975 Lett. 59, 343-354. https://doi.org/10.1016/0012-821X(82)90136-4

976

977 Iglseder, C., Grasemann, B., Rice, A.H.N., Petrakakis, K., Schneider, D.A. (2011). Miocene south 978 directed low-angle normal fault evolution on Kea Island (West Cycladic Detachment System, Greece): 979 WEST CYCLADIC DETACHMENT SYSTEM ON KEA. Tectonics 30. 980 https://doi.org/10.1029/2010TC002802

981

982 Jackson, J., McKenzie, D. (1999). A hectare of fresh striations on the Arkitsa Fault, central Greece. J. 983 Struct. Geol. 21, 1-6. https://doi.org/10.1016/S0191-8141(98)00091-1

985 Jolivet, L. (2003). Subduction tectonics and exhumation of high-pressure metamorphic rocks in the 986 Mediterranean orogens. Am. J. Sci. 303, 353-409. https://doi.org/10.2475/ajs.303.5.353 
988 Jolivet, L., Lecomte, E., Huet, B., Denèle, Y., Lacombe, O., Labrousse, L., Le Pourhiet, L., Mehl, C. 989 (2010a). The North Cycladic Detachment System. Earth Planet. Sci. Lett. 289, 87-104. 990 https://doi.org/10.1016/j.eps1.2009.10.032

991

992 Jolivet, L., Trotet, F., Monié, P., Vidal, O., Goffé, B., Labrousse, L., Agard, P., Ghorbal, B. (2010b).

993 Along-strike variations of $\mathrm{P}-\mathrm{T}$ conditions in accretionary wedges and syn-orogenic extension, the HP994 LT Phyllite-Quartzite Nappe in Crete and the Peloponnese. Tectonophysics 480, 133-148. 995 https://doi.org/10.1016/j.tecto.2009.10.002

996

997 Jolivet, L., Faccenna, C., Huet, B., Labrousse, L., Le Pourhiet, L., Lacombe, O., Lecomte, E., Burov, 998 E., Denèle, Y., Brun, J-P., Philippon, M., Paul, A., Salaün, G., Karabulut, H., Piromallo, C., Monié, P., 999 Gueydan, F., Okay, A.I., Oberhänsli, R., Pourteau, A., Augier, R., Gadenne, L., Driussi, O. (2013). 1000 Aegean tectonics: Strain localisation, slab tearing and trench retreat. Tectonophysics 597-598, 1-33. https://doi.org/10.1016/j.tecto.2012.06.011

1002

Katsikatsos, G., Brujin, D., Van der Meulen, A.J. (1981). The Neogene of the island of Euboea (Evia). Geol. En Mijnb. 60, 509-516.

Katsikatsos, G., Migiros, G., Triantaphyllis, M., Mettos, A. (1986). Geological structure of internal Hellenides (E. Thessaly-SW. Macedonia, Euboea-Attica-Northern Cyclades islands and Lesvos). Geōlogikai Kai Geōfusikai Meletai 191-212.

Katzir, Y., Avigad, D., Matthews, A., Garfunkel, Z., Evans, B.W. (2000). Origin, HP/LT metamorphism and cooling of ophiolitic melanges in southern Evia (NW Cyclades), Greece. J. Metamorph. Geol. 18, 699-718. https://doi.org/10.1046/j.1525-1314.2000.00281.x

Kiratzi, A., Louvari, E. (2003). Focal mechanisms of shallow earthquakes in the Aegean Sea and the surrounding lands determined by waveform modelling: a new database. J. Geodyn. 36, 251-274. https://doi.org/10.1016/S0264-3707(03)00050-4

1018 Kissel, C., Laj, C., Mazaud, A. (1986). First paleomagnetic results from Neocene Formations in Evia, 1019 Skyros and the Volos Region and the deformation of Central Aegea. Geophys. Res. Lett. 13, 14461449. https://doi.org/10.1029/GL013i013p01446

1022 Kissel, C., Laj, C., Poisson, A., Görür, N. (2003). Paleomagnetic reconstruction of the Cenozoic 1023 evolution of the Eastern Mediterranean. Tectonophysics 362, 199-217. https://doi.org/10.1016/S0040- 
Kokkalas, S. (2001). Tectonic evolution and stress field of the Kymi-Aliveri basin, Evia island, Greece. Bull. Geol. Soc. Greece 34, 243. https://doi.org/10.12681/bgsg.17019

Kokkalas, S. (2010). SEGMENTATION AND INTERACTION OF NORMAL FAULTS IN

Kokkalas, S., Aydin, A. (2013). Is there a link between faulting and magmatism in the south-central Aegean Sea? Geol. Mag. 150, 193-224. https://doi.org/10.1017/S0016756812000453

Kokkalas, S., Xypolias, P., Koukouvelas, I., Doutsos, T. (2006). Postcollisional contractional and extensional deformation in the Aegean region, in: Postcollisional Tectonics and Magmatism in the Mediterranean Region and Asia. Geological Society of America. https://doi.org/10.1130/0-8137-24090.97

1039

Kokkalas, S., Jones, R.R., McCaffrey, K.J.W., Clegg, P. (2007). Quantitative fault analysis at Arkitsa, 1041 Central Greece, using Terrestrial Laser- Scanning (“LIDAR”). Bull. Geol. Soc. Greece 40, 1959. https://doi.org/10.12681/bgsg.17237

1044 Koukouvelas, I.K., Kokkalas, S. (2003). Emplacement of the Miocene west Naxos pluton (Aegean Sea, 1045 Greece): a structural study. Geol. Mag. 140, 45-61. https://doi.org/10.1017/S0016756802007094

1047 Krohe, A., Mposkos, E., Diamantopoulos, A., Kaouras, G. (2010). Formation of basins and mountain ranges in Attica (Greece): The role of Miocene to Recent low-angle normal detachment faults. EarthSci. Rev. 98, 81-104. https://doi.org/10.1016/j.earscirev.2009.10.005

Liati, A., Skarpelis, N., Pe-Piper, G. (2009). Late Miocene magmatic activity in the Attic-Cycladic Belt of the Aegean (Lavrion, SE Attica, Greece): implications for the geodynamic evolution and timing of ore deposition. Geol. Mag. 146, 732-742. https://doi.org/10.1017/S0016756809006438

1055 Lister, G.S., Banga, G., Feenstra, A. (1984). Metamorphic core complexes of Cordilleran type in the Cyclades, Aegean Sea, Greece 6.

Lykousis, V., Sakellariou, D., Moretti, I., \& Kaberi, H. (2007). late Quaternary basin evolution of the 1059 Gulf of Corinth: Sequence stratigraphy, sedimentation, fault-slip and subsidence rates. Tectonophysics, 440(1-4), 29-51. https://doi.org/10.1016/j.tecto.2006.11.007 
1062 Malandri, C., Soukis, K., Maffione, M., Özkaptan, M., Vassilakis, E., Lozios, S., van Hinsbergen, D.J.J.

1063 (2017). Vertical-axis rotations accommodated along the Mid-Cycladic lineament on Paros Island in the

1064 extensional heart of the Aegean orocline (Greece). Lithosphere 9, 78-99.

1065 https://doi.org/10.1130/L575.1

1066

1067 Mascle, J., Martin, L. (1990). Shallow structure and recent evolution of the Aegean Sea: A synthesis 1068 based on continuous reflection profiles. Mar. Geol. 94, 271-299. https://doi.org/10.1016/00251069 3227(90)90060-W

McClusky, S., Balassanian, S., Barka, A., Demir, C., Ergintav, S., Georgiev, I., Gurkan, O., Hamburger,

1072 M., Hurst, K., Kahle, H., Kastens, K., Kekelidze, G., King, R., Kotzev, V., Lenk, O., Mahmoud, S., 1073 Mishin, A., Nadariya, M., Ouzounis, A., Paradissis, D., Peter, Y., Prilepin, M., Reilinger, R., Sanli, I.,

1074 Seeger, H., Tealeb, A., Toksöz, M.N., Veis, G. (2000). Global Positioning System constraints on plate

1075 kinematics and dynamics in the eastern Mediterranean and Caucasus. J. Geophys. Res. Solid Earth 105, 5695-5719. https://doi.org/10.1029/1999JB900351

1077

McDowell, F.W., McIntosh, W.C., Farley, K.A. (2005). A precise 40Ar-39Ar reference age for the Durango apatite (U-Th)/He and fission-track dating standard. Chem. Geol. 214, 249-263. https://doi.org/10.1016/j.chemgeo.2004.10.002 mantle flow, crustal dynamics and magma genesis associated with slab roll-back and tearing: The eastern Mediterranean case. Earth Planet. Sci. Lett. 442, 93-107. https://doi.org/10.1016/j.eps1.2016.03.002

Mettos, A., Rondogianni, Th., Papadakis, G., Pashos, P., Georgiou, H. (1991). New data on the geology of the Neogene deposits of N. Evia. Bull. Geol. Soc. Greece 25, 71-83.

Mettos, A., Rondogianni, Th., Ioakim, Ch., Papadakis, I. (1992). Evolution geodynamique et reconstruction paleoenvironnementale des basins Neogenes-Quaternaires de la Grece centrale. Paleontol. Evolucio 24-25, 393-402.

Moretti, I., Sakellariou, D., Lykousis, V., Micarelli, L. (2003). The Gulf of Corinth: an active half graben? J. Geodyn. 36, 323-340. https://doi.org/10.1016/S0264-3707(03)00053-X

1097 Most, T. (2003). Geodynamic evolution of the Eastern Pelagonian Zone in northwestern Greece and the 
1098 Republic of Macedonia. Implications from $\mathrm{U} / \mathrm{Pb}, \mathrm{Rb} / \mathrm{Sr}, \mathrm{K} / \mathrm{Ar}, \mathrm{Ar} / \mathrm{Ar}$, geochronology and fission track 1099 thermochronology. (Doctoral dissertation). Tubingen, Germany.

1101 Nirta, G., Moratti, G., Piccardi, L., Montanari, D., Catanzariti, R., Carras, N., Papini, M. (2015). The 1102 Boeotian Flysch revisited: new constraints on ophiolite obduction in Central Greece. Ofioliti 40. 1103 https://doi.org/10.4454/ofioliti.v40i2.438

Nuriel, P., Craddock, J., Kylander-Clark, A.R.C., Uysal, I.T., Karabacak, V., Dirik, R.K., Hacker, B.R., Weinberger, R. (2019). Reactivation history of the North Anatolian fault zone based on calcite agestrain analyses. Geology 47, 465-469. https://doi.org/10.1130/G45727.1

Papanikolaou, D. (1997). The tectonostratigraphic terranes of the Hellenides. Ann. Geol. Pays Hell. 37, 495-514.

1112 Papanikolaou, D. (2013). Tectonostratigraphic models of the Alpine terranes and subduction history of

1113 the Hellenides. Tectonophysics 595-596, 1-24. https://doi.org/10.1016/j.tecto.2012.08.008

Papanikolaou, D.J., Royden, L.H. (2007). Disruption of the Hellenic arc: Late Miocene extensional detachment faults and steep Pliocene-Quaternary normal faults-Or what happened at Corinth?: DISRUPTION OF THE HELLENIC ARC. Tectonics 26. https://doi.org/10.1029/2006TC002007

1119 Pe-Piper, G., Piper, D.J.W. (1994). Miocene magnesian andesites and dacites, Evia, Greece: adakites 1120 associated with subducting slab detachment and extension. Lithos 31, 125-140. 1121 https://doi.org/10.1016/0024-4937(94)90004-3

Pérouse, E., Chamot-Rooke, N., Rabaute, A., Briole, P., Jouanne, F., Georgiev, I., Dimitrov, D. (2012). Bridging onshore and offshore present-day kinematics of central and eastern Mediterranean: Implications for crustal dynamics and mantle flow: CENTRAL TO EAST MEDITERRANEAN KINEMATICS. Geochem. Geophys. Geosystems 13. https://doi.org/10.1029/2012GC004289

1128 Philip, H. (1987), Plio-Quaternary evolution of the stress field in Mediterranean zones of subduction and collision, Annales Geophysicae, 5B, 301-320. segmented Cycladic Blueschist Unit (Central Aegean, Greece). Tectonophysics 524-525, 116-134. https://doi.org/10.1016/j.tecto.2011.12.025 
1135 Philippon, M., Gueydan, F., Pitra, P., Brun, J-P. (2013). Preservation of subduction-related prograde

1136 deformation in lawsonite pseudomorph-bearing rocks. J. Metamorph. Geol. 31, 571-583.

1137 https://doi.org/10.1111/jmg.12035

1139 Rabillard, A., Arbaret, L., Jolivet, L., Le Breton, N., Gumiaux, C., Augier, R., Grasemann, B. (2015).

1140 Interactions between plutonism and detachments during metamorphic core complex formation, Serifos

1141 Island (Cyclades, Greece): PLUTONISM - STRAIN LOCALIZATION. Tectonics 34, 1080-1106.

1142 https://doi.org/10.1002/2014TC003650

1144 Reilinger, R.E., McClusky, S.C., Oral, M.B., King, R.W., Toksoz, M.N., Barka, A.A., Kinik, I., Lenk, 1145 O., Sanli, I. (1997). Global Positioning System measurements of present-day crustal movements in the 1146 Arabia-Africa-Eurasia plate collision zone. J. Geophys. Res. Solid Earth 102, 9983-9999. 1147 https://doi.org/10.1029/96JB03736

1149 Reilinger, R., McClusky, S., Vernant, P., Lawrence, S., Ergintav, S., Cakmak, R., Ozener, H., Kadirov, 1150 F., Guliev, I., Stepanyan, R., Nadariya, M., Hahubia, G., Mahmoud, S., Sakr, K., ArRajehi, A., 1151 Paradissis, D., Al-Aydrus, A., Prilepin, M., Guseva, T., Evren, E., Dmitrotsa, A., Filikov, S.V., Gomez, 1152 F., Al-Ghazzi, R., Karam, G. (2006). GPS constraints on continental deformation in the Africa-Arabia1153 Eurasia continental collision zone and implications for the dynamics of plate interactions: EASTERN

1154 MEDITERRANEAN ACTIVE TECTONICS. J. Geophys. Res. Solid Earth 111. 1155 https://doi.org/10.1029/2005JB004051

1157 Ring, U., Layer, P.W., Reischmann, T. (2001). Miocene high-pressure metamorphism in the Cyclades 1158 and Crete, Aegean Sea, Greece: Evidence for large-magnitude displacement on the Cretan detachment 11595.

1160

1161 Ring, U., Thomson, S.N., Bröcker, M. (2003). Fast extension but little exhumation: the Vari detachment 1162 in the Cyclades, Greece. Geol. Mag. 140, 245-252. https://doi.org/10.1017/S0016756803007799

1164 Ring, U., Glodny, J., Will, T., Thomson, S. (2007). An Oligocene extrusion wedge of blueschist-facies 1165 nappes on Evia, Aegean Sea, Greece: implications for the early exhumation of high-pressure rocks. J. 1166 Geol. Soc. 164, 637-652. https://doi.org/10.1144/0016-76492006-041

1168 Roberts, S., Jackson, J. (1991). Active normal faulting in central Greece: an overview. Geol. Soc. Lond. Spec. Publ. 56, 125-142. https://doi.org/10.1144/GSL.SP.1991.056.01.09

1171 Ross, J.V., Zimmerman, J. (1996). Comparison of evolution and tectonic significance of the Pindos and 
1172 Vourinos ophiolite suites, northern Greece. Tectonophysics 256, 1-15. https://doi.org/10.1016/0040-

1173 1951(95)00160-3

1174

1175 Royden, L.H., Papanikolaou, D.J. (2011). Slab segmentation and late Cenozoic disruption of the

1176 Hellenic arc: DISRUPTION OF THE HELLENIC ARC. Geochem. Geophys. Geosystems 12.

1177 https://doi.org/10.1029/2010GC003280

1178

1179 Sakellariou, D., Tsampouraki-Kraounaki, K. (2019). Plio-Quaternary Extension and Strike-Slip

1180 Tectonics in the Aegean, in: Transform Plate Boundaries and Fracture Zones. Elsevier, pp. 339-374.

1181 https://doi.org/10.1016/B978-0-12-812064-4.00014-1

1182

1183 Sakellariou, D., Mascle, J., \& Lykousis, V. (2013). Strike slip tectonics and transtensional deformation

1184 in the Aegean region and the Hellenic arc: Preliminary results. Bulletin of the Geological Society of

1185 Greece, 47(2), 647. https://doi.org/10.12681/bgsg.11098

1186

1187 Scheffer, C., Vanderhaeghe, O., Lanari, P., Tarantola, A., Ponthus, L., Photiades, A., France, L. (2016).

1188 Syn- to post-orogenic exhumation of metamorphic nappes: Structure and thermobarometry of the

1189 western Attic-Cycladic metamorphic complex (Lavrion, Greece). J. Geodyn. 96, 174-193.

1190 https://doi.org/10.1016/j.jog.2015.08.005

1191

1192 Schenker, F.L., Fellin, M.G., Burg, J.-P. (2015). Polyphase evolution of Pelagonia (northern Greece)

1193 revealed by geological and fission-track data. Solid Earth 6, 285-302. https://doi.org/10.5194/se-6-285-

11942015

1195

1196 Schneider, D.A., Grasemann, B., Lion, A., Soukis, K., Draganits, E. (2018). Geodynamic significance

1197 of the Santorini Detachment System (Cyclades, Greece). Terra Nova 30, 414-422.

1198 https://doi.org/10.1111/ter.12357

1199

1200 Seman, S.M., (2016). The tectonostratigraphy of the Cycladic Blueschist Unit and new garnet 1201 geo/thermochronology techniques (Doctoral dissertation). University of Texas, Austin.

1203 Şengör, A.M.C. (1979). The North Anatolian transform fault: its age, offset and tectonic significance.

1204 Journal of the Geological Society, 136(3), 269-282. https://doi.org/10.1144/gsjgs.136.3.0269

1206 Şengör, A.M.C., Tüysüz, O., İmren, C., Sakınç, M., Eyidoğan, H., Görür, N., Le Pichon, X., Rangin, 1207 C. (2005). THE NORTH ANATOLIAN FAULT: A NEW LOOK. Annu. Rev. Earth Planet. Sci. 33, 1208 37-112. https://doi.org/10.1146/annurev.earth.32.101802.120415 
1210 Seward, D., Spikings, R., Viola, G., Kounov, A., Ruiz, G.M.H., Naeser, N. (2000). Etch times and

1211 operator variation for spontaneous track length measurements in apatites: an intra-laboratory check.

1212 OnTrack, $10(21), 16-21$.

1213

1214 Seward, D., Vanderhaeghe, O., Siebenaller, L., Thomson, S., Hibsch, C., Zingg, A., Holzner, P., Ring,

1215 U., Duchêne, S. (2009). Cenozoic tectonic evolution of Naxos Island through a multi-faceted approach

1216 of fission-track analysis. Geol. Soc. Lond. Spec. Publ. 321, 179-196. https://doi.org/10.1144/SP321.9

1218 Shaked, Y., Avigad, D., Garfunkel, Z. (2000). Alpine high-pressure metamorphism at the

1219 Almyropotamos window (southern Evia, Greece). Geol. Mag. 137, 367-380.

1220 https://doi.org/10.1017/S001675680000426X

Sobel, E.R., Seward, D. (2010). Influence of etching conditions on apatite fission-track etch pit diameter. Chem. Geol. 271, 59-69. https://doi.org/10.1016/j.chemgeo.2009.12.012

Sorel, D. (2000). A Pleistocene and still-active detachment fault and the origin of the Corinth-Patras rift, Greece 4.

Soukis, K., Stockli, D.F. (2013). Structural and thermochronometric evidence for multi-stage exhumation of southern Syros, Cycladic islands, Greece. Tectonophysics 595-596, 148-164. https://doi.org/10.1016/j.tecto.2012.05.017 of the Ionian Zone of Albania. Geophys. Res. Lett. 19, 697-700. https://doi.org/10.1029/92GL00575

Stefatos, A., Papatheodorou, G., Ferentinos, G., Leeder, M., \& Collier, R. (2002). Seismic reflection imaging of active offshore faults in the Gulf of Corinth: their seismotectonic significance. Basin Research, 14(4), 487-502. https://doi.org/10.1046/j.1365-2117.2002.00176.x

Tagami, T. (1987). Determination of zeta calibration constant for fission track dating. Int. J. Radiat.

1240 Appl. Instrum. Part Nucl. Tracks Radiat. Meas. 13, 127-130. https://doi.org/10.1016/1359$1241 \quad 0189(87) 90023-9$

1243 Thomson, S. N., Ring, U., Brichau, S., Glodny, J., \& Will, T. M. (2009). Timing and nature of formation 1244 of the Ios metamorphic core complex, southern Cyclades, Greece. Geological Society, London, Special Publications, 321(1), 139-167. https://doi.org/10.1144/SP321.7 
1247 Trotet, F., Vidal, O., Jolivet, L. (2001). Exhumation of Syros and Sifnos metamorphic rocks (Cyclades,

1248 Greece). New constraints on the P-T paths. Eur. J. Mineral. 13, 901-920. https://doi.org/10.1127/0935-

$1249 \quad 1221 / 2001 / 0013 / 0901$

1250

1251 Tschegg, C., Grasemann, B. (2009). Deformation and alteration of a granodiorite during low-angle 1252 normal faulting (Serifos, Greece). Lithosphere 1, 139-154. https://doi.org/10.1130/L33.1

Vamvaka, A., Spiegel, C., Frisch, W., Danišík, M., Kilias, A. (2010). Fission track data from the Mesohellenic Trough and the Pelagonian zone in NW Greece: Cenozoic tectonics and exhumation of source areas. Int. Geol. Rev. 52, 223-248. https://doi.org/10.1080/00206810802674402

Vandenberg, L.C., Lister, G.S. (1996). Structural analysis of basement tectonites from the Aegean metamorphic core complex of Ios, Cyclades, Greece. J. Struct. Geol. 18, 1437-1454. https://doi.org/10.1016/S0191-8141(96)00068-5

van Hinsbergen, D.J.J., Schmid, S.M. (2012). Map view restoration of Aegean-West Anatolian accretion and extension since the Eocene: RESTORATION OF THE AEGEAN REGION. Tectonics 31. https://doi.org/10.1029/2012TC003132

van Hinsbergen, D.J.J., Langereis, C.G., Meulenkamp, J.E. (2005). Revision of the timing, magnitude and distribution of Neogene rotations in the western Aegean region. Tectonophysics 396, 1-34. https://doi.org/10.1016/j.tecto.2004.10.001

van Hinsbergen, D.J.J., van der Meer, D.G., Zachariasse, W.J., Meulenkamp, J.E. (2006). Deformation of western Greece during Neogene clockwise rotation and collision with Apulia. Int. J. Earth Sci. 95, 463-490. https://doi.org/10.1007/s00531-005-0047-5

1275 N. (2007). Discrete Plio-Pleistocene phases of tilting and counterclockwise rotation in the southeastern

1276 Aegean arc (Rhodos, Greece): early Pliocene formation of the south Aegean left-lateral strike-slip 1277 system. Journal of the Geological Society, 164(6), 1133-1144. https://doi.org/10.1144/0016-76492006061

1280 van Hinsbergen, D.J.J., Dekkers, M. J., \& Kroc, A. (2010). Testing Miocene Remagnetization of Bey 1281 Dağları: Timing and Amount of Neogene Rotations in SW Turkey. Turkish Journal of Earth Sciences, $128219(2), 123-156$. 
1284 Walcott, C.R., White, S.H. (1998). Constraints on the kinematics of post-orogenic extension imposed 1285 by stretching lineations in the Aegean region. Tectonophysics 298, 155-175. 1286 https://doi.org/10.1016/S0040-1951(98)00182-6

1288 Wallace, R. E. (1951), Geometry of shearing stress and relation to faulting, The Journal of Geology, $59,118-130$.

Walker, R.T., Claisse, S., Telfer, M., Nissen, E., England, P., Bryant, C., Bailey, R. (2010). Preliminary estimate of Holocene slip rate on active normal faults bounding the southern coast of the Gulf of Evia, central Greece. Geosphere 6, 583-593. https://doi.org/10.1130/GES00542.1 American Geophysical Union, 72(41), 441-446.

Xypolias, P., Kokkalas, S., Skourlis, K. (2003). Upward extrusion and subsequent transpression as a possible mechanism for the exhumation of HP/LT rocks in Evia Island (Aegean Sea, Greece). J. Geodyn. 35, 303-332. https://doi.org/10.1016/S0264-3707(02)00131-X

Yarwood, G.A., Aftalion, M. (1976). Field relations and U-Pb geochronology of a granite from the

1303 Pelagonian Zone of the Hellenides (High Pieira, Greece). Bull. Société Géologique Fr. 7, 259-264. https://doi.org/7(2), 259-264. https://doi.org/10.2113/gssgfbull.S7-XVIII.2.259

\section{Figure captions}

1308 Figure 1: Simplified tectonics map of the Aegean with different continental terranes (Rhodope, 1309 Pelagonia, Adria; modified after Bradley et al., 2013; Papanikolaou, 2013; Brun et al., 2016), deep 1310 basins and/or oceans (Vardar, Pindos) and main faults or deformation zones: NAF: North Anatolian 1311 Fault; NAT: North Aegean Trough; CHSZ: Central Hellenic Shear Zone; MIF: Myrthes-Ikaria Fault,

1312 the Pelagonian Fault. middle Miocene basins in dark Orange and syn-tectonics Miocene plutons 1313 (Koukouvelas and Kokkalas, 2003; Kokkalas and Aydin, 2013) in red. Low-temperature data from Hejl 1314 et al., 1999, 2008; Most, 2003; Thomson et al., 2009; Vamvaka et al., 2010; Coutand et al., 2014; 1315 Schenker et al., 2015 for Pelagonia; Hejl et al., 2002, 2008; Ring et al., 2003, 2007; Brichau et al., 1316 2006, 2008; Seward et al., 2009; Berger et al., 2013; Soukis and Stockli, 2013; Seman, 2016; 1317 Grasemann et al., 2018; Schneider et al., 2018 for the Cyclades. Curved arrow: North Aegean 1318 clockwise block rotation (Horner and Freeman, 1983; Kissel et al., 1986, 2003; Duermeijer, 2000; van 1319 Hinsbergen et al., 2005, 2006; Bradley et al., 2013) and counterclockwise rotation in south Aegean 
1320 (van Hinsbergen et al., 2007, 2010; van Hinsbergen and Schmid, 2012). Black arrows: average

1321 directions of Anatolia westward extrusion and southward Hellenic trench retreat related to slab 1322 rollback (Reilinger et al., 2006). Dashed box: study area in Central Greece. Inset: present-day GPS 1323 velocity field (modified from Hollenstein et al., 2008).

Figure 2: Tectonic map of Central Greece (location in Fig. 1) gathering our intrepretation (see text for details) and already published data (geology simplified from Bornovas and Rondogianni-Tsiambaou, 1983; Faupl et al., 2007; Nirta et al., 2015; and tectonics interpretation from Roberts and Jackson, 1991; Gautier and Brun, 1994; Jackson and McKenzie, 1999; Goldsworthy et al., 2002; Kokkalas et al., 2007; Lykousis et al., 2007; Bell et al., 2009; Kokkalas, 2010; Krohe et al., 2010; Walker et al., 2010) . Coexistence of $N W$-striking normal faults (red) and NE-striking dextral strike-slip faults (Pelagonian fault strike-slip corridor in orange) during middle Miocene basins deposition (in yellow); and younger E-W normal faulting (black) during Plio-Quaternary basins deposition (in light yellow). Grey diamonds: AFT samples. Dashed boxes: location of local studies (Limni basin shown in Fig. 3, Loutra Ypatis shown in Fig. 4 and Kymi basin shown in Fig. 6).

Figure 3: Structural features of the Limni basin (location in Fig. 2). A/ structural map (modified from Bornovas and Rondogianni-Tsiambaou, 1983; Bono et al., 1998) of the Limni basin with basin bedding, basement foliation and main inferred normal faults (NW-striking in red and E-striking in black). "I, II, IV, V': sites of measurements shown in B/. Grey diamonds: AFT samples. B/ Stereonets for measurements made in different key locations, shown in A/, with fault and basin bedding. Dip-slip slickenlines associated with $\mathrm{NW}$-striking normal faults are represented by red circles and oblique slickenlines associated with $N W$-striking sinistral faults are represented by purple circles. Slickenlines with a rake $\leq 45^{\circ}$ are considered as oblique. C/ NNE-SSW a' '- a cross section (profile drawn in A/). Fault numbering shown also in map A/. D/Outcrop pictures. Left: dip-slip slickenlines in NW-striking normal fault plane (location II shown in A/, B/ and C/); right: cross-cutting relation between $N W$ striking and E-striking normal fault (location I shown in A/, B/ and C/).

Figure 4: Structural features in the Loutra Ypatis area (location in Fig. 2). A/ Structural map (modified after Bornovas and Rondogianni-Tsiambaou, 1983; Faupl et al., 2007; Nirta et al., 2015) with main inferred normal faults (NW-striking in red and E-striking in black). "I, II, III, IV, V": key locations of measurements shown in B, "a,b,c": location of outcrop pictures shown in C/. Arkitsa fault geometry from Jackson and McKenzie, 1999; Kokkalas et al., 2007. Grey diamonds: AFT samples. B/ Stereonets

1353 for fault measurements made in different sites (shown in A/) with NW-striking normal faults in red and

1354 E-striking normal faults in black. Dip-slip slickenlines associated with NW-striking normal faults et E$W$ normal faults are respectively represented by red and black circles. Oblique slickenline associated with $N W$-striking sinistral fault is represented by purple circle. C/ Outcrop pictures: slickenlines in

1357 Kamena Vourla fault planes (locations $a$ and $b$ in A/) and E-striking fault plane (location c in A/). 
1359 Figure 5: Stress inversion results (Fault and Stress Analysis software) for Plio-Quaternary (A) and 1360 middle Miocene (B) fault families measured in Limni (Fig. 3) and Loutra Ypatis (Fig. 4) area. A/Stress 1361 inversion tensor result $T_{12}$ for E-striking normal faults (family 1) and NW-striking oblique (sinistral)

1362 faults (family 2): sub-vertical $s_{1}$, sub-horizontal and radial extension with $N-S S_{3} . A-1$ : Left lower 1363 hemisphere Schmidt stereographic representation of the fault slip data. A-2: lower hemisphere Schmidt 1364 stereographic projection of the principal stress orientations. Circle, square and triangle correspond to $1365 s_{1}, s_{2}, s_{3}$, respectively. A-3: Plio-Quaternary schematic tectonics map with $N$-S extension associated 1366 with E-striking normal fault and oblique slip on NW-striking faults and Plio-Quaternary basins. B/ 1367 Stress inversion tensor result $T_{3}$ for $N W$-striking normal faults (with dip slip motion, family 3) with $N E$ $1368 S W S_{3} . B-1$ and B-2: same convention as in A/, B-3: middle Miocene schematic tectonics map with NE$1369 S W$ extension with dip-slip motion on $N W$-striking normal faults and middle Miocene basin deposition.

1371 Figure 6: Structural features of the Kymi basin area (location in Fig. 2). A/ Structural map (modified 1372 after Bornovas and Rondogianni-Tsiambaou, 1983; Bradley, 2012) of the Kymi basin with inferred 1373 main NW-striking normal faults (red) and NE-striking dextral strike-slip faults (orange), basin bedding and basement foliations. Large scale folds from West to East: Amarynthos antiform, Kymi syncline, Almyropotamos antiform (Xypolias et al., 2003). "I, II, III, IV, V, VI, VII": zones of measurements shown on stereonets in B/. Grey diamonds: AFT samples. B/ Stereonets for fault measurements and basin bedding conduced in several key locations (shown in A/). C/ Outcrop pictures showing subhorizontal slickenlines on NE-striking fault plane (zone IV in A/). D/Outcrop picture in location III showing new NE-striking shistosity inside a NE-striking sub-vertical fault zone. E/ The Kymi basin cross-section (profile drawn in A/) orthogonal to the NE-striking Pelagonian dextral strike-slip fault

1382 Figure 7: Stress tensor inversion result $T_{4}$ for NE-striking dextral strike-slip faults (family 4, measured 1383 in Kymi area, Fig. 6). A/ Left lower hemisphere Schmidt stereographic representation of the fault slip 1384 data. B/lower hemisphere Schmidt stereographic projection of the principal stress orientations. Circle, square and triangle correspond to $s_{1}, s_{2}, s_{3}$, respectively. C/ Schematic tectonics map of the Kymi basin deposition controlled by NE-striking strike-slip faults with N-S extension and E-W compression, compatible with observed large-scale open folds.

1389 Figure 8: Single crystal apatite fission track age distribution of the samples presented in radial plots 1390 (Galbraith, 1990, 2005) and age spectra. Samples location in Fig. 2. Radial plots were made using the 1391 Trackkey software (Dunkl, 2002). The light-blue shade represents the estimated stratigraphic age of 1392 the sediment for each sample. The grey arrows point to the Oligocene cooling phase and the red arrows 1393 to the Miocene cooling phase, if present. Red vertical dashed line: Oligocene-Miocene boundary. A/ 
1394 Results for Sample CG03; B/ Results for Sample CG08; C/ Results for Sample CG11; D/ Results for

1395 Sample CG13; E/ Results for Sample CG14; F/ Results for Sample CG16.

1397 Figure 9: Synthesis of low-thermochronology data in Central Greece and the Cyclades, highlighting 1398 the major differences in exhumation history between the Cycladic Blueschist Unit (CBU, in blue) and 1399 the Pelagonian-derived rocks (in pink). A/ Simplified map (geology simplified from Papanikolaou, 1400 2013; Brun et al., 2016) with a synthesis of low-temperature thermochronology ages from this study 1401 (circle for AFT) and from previous studies (diamond for AFT, triangle for Zircon Fission Track-ZFT, 1402 hexagon and square for (U-Th)/He age in respectively Zircon and Apatite) in both Central Greece and 1403 the Cyclades. Data from Hejl et al., 1999, 2008; Most, 2003; Thomson et al., 2009; Vamvaka et al., 1404 2010; Coutand et al., 2014; Schenker et al., 2015; and Cyclades/South Evvia/Attica datation from Hejl 1405 et al., 2002, 2008; Ring et al., 2003, 2007; Brichau et al., 2006, 2008; Seward et al., 2009; Berger et 1406 al., 2013; Soukis and Stockli, 2013; Seman, 2016; Grasemann et al., 2018; Schneider et al., 2018). B/ 1407 Low-temperature thermochronology ages along a NE-SW transect (location as black line in A/) 1408 orthogonal to the Pelagonian fault. AFT, ZFT, and (U-Th)/He on Zircon and Apatites ages respectively 1409 as diamonds, triangles, stars and square. AFT data from this study as circle. Colors refer to different 1410 references (see A/). Thick pink and blue lines: mean low temperature age calculated in Pelagonian 1411 rocks and in the Cycladic rocks. Thick dashed line: Pelagonian fault. See text for further explanations. 1412 References: (a) Berger et al., 2013 - (b) Brichau et al., 2006 - (c) Brichau et al., 2008 - (d) Coutand et 1413 al., 2014 - (e) Grasemann et al., 2018 - (f) Hejl et al., 1999 - (g) Hejl et al., 2002 - (h) Hejl et al., 2008 1414 - (i) Most, 2003 - (j) Ring et al., 2003 - (k) Ring et al., 2007 - (l) Schenker et al., 2015 - (m) Schneider 1415 et al., 2018 - (n) Seward et al., 2009 - (o) Soukis and Stockli, 2013 - (p)PhD of Seman, 2016 - (q) 1416 Thomson et al., 2009 - (r) Vamvaka et al., 2010.

1417 Figure 10: Stress inversion and stress compatibilities between NE-striking dextral faults, NW-striking 1418 high-angle normal faults and E-striking high-angle normal faults. A/ Stress inversion results for the 1419 combination of $N W$-striking normal faults (with dip-slip, family 3) and NE-striking dextral strike-slip 1420 (family 4). B/Inferred stress tensor solution T34. Same conventions as Fig. 5. WNW s1 and NNE s3; C/ 1421 Stress inversion results for the combination of back-rotated NW-striking normal faults (with dip-slip, 1422 family 3r) and NE-striking dextral strike-slip (family 4). D/ Stress tensor solution $T_{3 r 4}$, with back1423 rotated $N W$-striking normal faults. $N-S s 3$ and E-W s1. E/ Tectonic regime diagram (Armijo et al., 1982; 1424 Philip, 1987; Célérier, 1995). Left: each stress tensor is represented by an open circle. Center: the 1425 three tectonics regimes of Anderson (1905) are designated by the vertical principal stress Sv. Right: 1426 stress tensor aspect ratio $r_{0}=\left(\sigma_{1}-\sigma_{2}\right) /\left(\sigma_{1}-\sigma_{3}\right)$.

1428 Figure 11: Schematic tectonics reconstruction of Central Greece from middle Miocene to Present 1429 (simplified from Royden and Papanikolaou, 2011) and position of the Hellenic trench and emerged 1430 area in the Aegean domain in inset (right corners). A/ middle to late Miocene before block rotation 
1431 (back-rotated position): with NE-striking dextral strike-slip faults and restored position of the $N W$ -

1432 striking normal faults (almost E-striking after a $30^{\circ}$ of back-rotation), respectively accommodating 1433 initiating westward Anatolia extrusion and ongoing Hellenic trench retreat. On the right: middle

1434 Miocene Stress Tensor before rotation (T3r, Fig. 10).B/ middle to late Miocene after block rotation(in 1435 present-day configuration): distributed deformation with coexistence of normal faults and dextral 1436 strike-slip fault. Block rotation, accommodated by dextral strike-slip faulting (see inset bottom left for 1437 clockwise rotation consistent with dextral faults) and subsequent rotation of normal faults (red). 1438 Extensional stress rotated subsequently from N-S (see A/) to NE-SW (stress tensor $T_{3}$ in red rectangle, 1439 from Fig. 5). Shortening direction are similar to A/in the strike-slip corridors (stress tensor $T_{4}$ in orange 1440 rectangle, from Fig. 7). C/ Plio-Quaternary: Formation of E-striking normal faults inside pre-existing $1441 \quad N W$-striking structures now associated to sinistral kinematics. Stress tensor $T_{12}$ (from Fig. 7) : radial 1442 extensional.

1444 Table. 1. Position of each sample is given in columns coordinates. $\rho$ s, $\rho i$ and $\rho d$ correspond respectively 1445 to spontaneous, induced and dosimeter track densities ( $\times 104 \mathrm{~cm}-2)$. Ns, Ni and Nd correspond 1446 respectively to the total number of spontaneous, induced and dosimeter tracks. $U$ is the calculated 1447 Uranium density. $P\left(\chi^{2}\right)$ is the probability in \% of $\chi 2$ for $v$ degrees of freedom (where $v=$ number of 1448 crystals - 1). Dpar is the mean fission-track pit diameter in $\mu$ m corrected following Sobel \& Seward 1449 (2010) using a correction factor of 0.825. Central age calculated for each sample are given in the last 1450 column. 